\title{
Displaced South Alpine and Dinaridic elements in the Mid-Hungarian Zone
}

\author{
Sándor Kovácst, János Haas \\ Geological, Geophysical and Space Science \\ Research Group of the Hungarian Academy of \\ Sciences
}

\begin{abstract}
The Mid-Hungarian Zone is a WSW-ENE trending composite structural unit in the basement of the Pannonian Basin that is made up of displaced crustal fragments (terranes) of South Alpine and Dinaridic origin. In the early stage of the Alpine evolution these fragments were located in various sectors of the NW Neotethys region, representing different paleogeographic settings from passive margin through continental slope to oceanic basement. Middle to Late Jurassic closure of the Neotethys led to the development of a suture zone made up of subduction-related complexes that can be followed all along the strike of the Dinarides. During the Cretaceous compressional stages, nappe stacks were formed from the accretionary complex and the fragments of the previously disrupted passive margin. Eastward extrusion (escape) of the ALCAPA Mega-unit during the Oligocene to Early Miocene led to large-scale displacement of fragments of this nappe stack, transporting them to their present-day position, and resulted in dispersal of the northwestern segment of the suture zone. The paper summarizes the basic characteristics of the dislocated blocks, evaluates their relationships and determines their original setting.
\end{abstract}

Key words: Pannonian Basin, Mid-Hungarian Zone, Mid-Hungarian Line, Periadriatic-Balaton Line, Neotethys, ophiolite mélange, displaced terranes

\section{Introduction}

Displaced crustal fragments (terranes) of South Alpine and Dinaridic origin occur in the basement of the Pannonian Basin, along an ENE-WSW trending strip that is defined in the present paper as the Mid-Hungarian Zone (MHZ). During the early stages of the Alpine evolution these fragments were located

Address: J. Haas: H-1117 Budapest, Pázmány P. sétány 1/c, Hungary, e-mail: haas@ludens.elte.hu Received: February 22, 2011; accepted: March 11, 2011 
relatively far from each other and developed within different paleogeographic settings. They approached their present day position as a result of eastward extrusion (escape) of the ALCAPA Mega-unit (composite terrane) during the Oligocene to Early Miocene (Kázmér and Kovács 1985), and were subjected to tectonic deformations due to opposite rotation directions of the ALCAPA and Tisza Mega-units in the Early Miocene (Márton and Márton 1978; Fodor et al. 1999; Márton and Fodor 2003).

The aim of the present paper is to display basic characteristics of the displaced blocks, which occur along the southern margin of ALCAPA, evaluate their relationships with the surrounding structural units, and determine their original setting, since this is of critical importance for the reconstruction of the geodynamic evolution and paleogeography of the entire region.

\section{Previous concepts}

Based on studies of fossil assemblages of Upper Paleozoic sequences in the Bükk Mts of NE Hungary, already Schréter $(1936,1943,1959)$ and Heritsch (1942, 1944) recognized close facies affinities to the Carnic Alps, the Julian Alps and the Dinarides. Balogh (1964) emphasized a striking similarity in terms of lithofacies and the fossil content of the Upper Paleozoic formations found in the Bükk Mts with those of the Jadar Block (Dinarides of West Serbia) and the Žažar area (Julian Alps of Slovenia), respectively, suggesting close paleogeographic relationships amongst the three areas during the Late Paleozoic. The concept of a Late Paleozoic marine connection between the Bükk, South Alpine and Dinaridic realms was supported by the discovery of fusulinidae-bearing limestone in exploration wells south of Lake Balaton (Majzon 1956). These few data provided the basis for Wein's proposal $(1969,1972)$ for the existence of a narrow seaway connecting the Julian Alps with the Bükk Mts area; he named this area as "Igal-Bükk eugeosyncline". In his later work, already influenced by the concepts of plate tectonics, Wein (1978) interpreted the facies similarity to have resulted from tectonic displacements. He considered the Balaton Line (BAL) as the eastern continuation of the Periadriatic Lineament (Fig. 1), and assumed that the Igal-Bükk unit presently located between the BAL and the Zagreb-Zemplén Line (referred to as the Central Hungarian Line by Szepesházy 1975) was a segment of the southern Tethyan belt prior to its large-scale displacement via wrench-faulting.

Fülöp et al. (1987) proposed the name Central Transdanubian Unit; Haas et al. (1988) suggested the name of Mid-Transdanubian Unit for the pre-Tertiary basement complex between the BAL and Central or Mid-Hungarian Line (hereafter MHL) within the territory of Hungary. The south-western continuation of the Mid-Transdanubian Unit in Croatia was called Zagreb Zone (Dimitrijević 1982) or Supradinaricum and was considered to be a part of the Internal Dinarides (Herak 1986). Pamić et al. (1997) called it the Hrvatsko Zagorje 


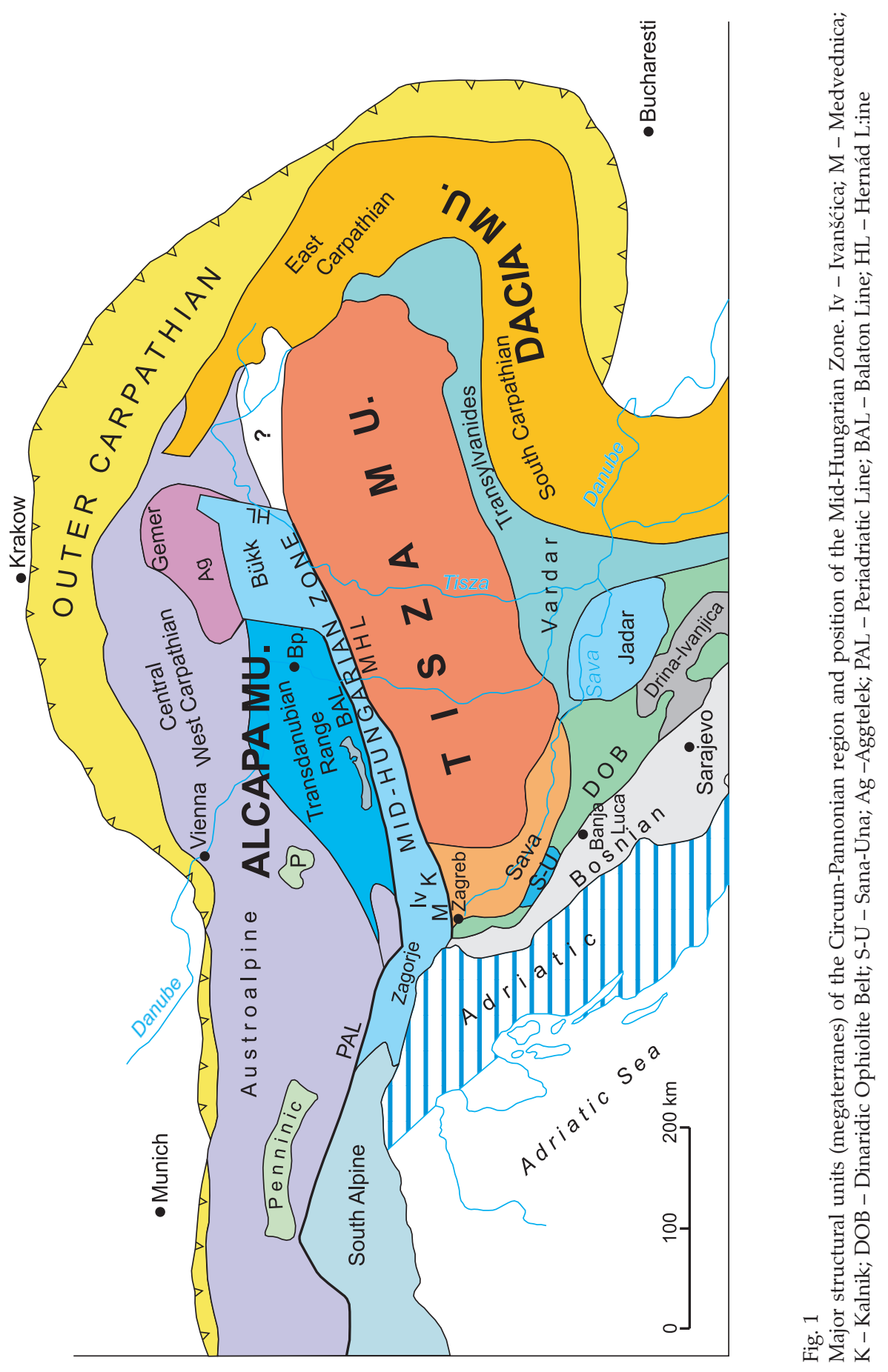

Central European Geology 53, 2010 
Terrane. Several authors assumed that the presence of Internal Dinaridic elements in the Mid-Transdanubian Zone was a result of strike-slip movements along the Zagreb-Zemplin Line (Dimitrijević 1974; Pamić 1997). Pamić and Tomljenović (1998) emphasized that formations exposed in the Hrvatsko Zagorje area (Medvednica, Ivanšćica and Kalnik Mts) which show characteristics of the Internal Dinarides, continue northeastward in the Mid-Transdanubian Unit. Accordingly, they proposed the name Zagorje-Mid-Transdanubian Zone for the entire unit.

To express the striking Dinaridic characteristics of the Bükk and the Neotethyan affinity of the Szarvaskő, Darnó and Meliata s.s. ophiolite mélanges, Pamić et al. (2002) and Pamić (2003) introduced the term Zagorje-Bükk-Meliata Zone. In the explanatory notes for the Circum-Pannonian tectonostratigraphic terrane map series (Kovács et al. 2004) this zone was named the Zagorje-BükkGemer Composite Terrane (Ebner et al. 2009; Vozárová et al. 2009; Kovács et al. 2010; Haas et al. 2010).

Balla (1984, 1987a) defined the term Mid-Hungarian Zone as a shear zone between the North Pannonian and South Pannonian tectonic units that contains strongly deformed fragments of the neighboring units, including the Szolnok flysch zone.

Brezsnyánszky and Haas (1986) and Fülöp et al. (1987) emphasized the critical geodynamic importance of the MHL as a microplate boundary (i.e. northern boundary of the Tisza Mega-unit) which determined the path of sizable horizontal displacements in the Tertiary.

Results of geologic mapping projects in the Bükk Mts and new borehole data in the Mid-Transdanubian and the Hrvatsko Zagorje areas in the 70s and 80s reinforced the South Alpine and Dinaridic facies affinity of the PaleozoicMesozoic rock sequences of these units. The facies affinity was explained by the proximity of the depositional areas, i.e. it was assumed that the Bükk Unit and the elements of the Mid-Transdanubian Unit were originally located in an intermediate region between the Southern Alps and the NW Dinarides from where they were squeezed out, reaching their recent position in the Tertiary (Kovács 1982; Haas et al. 1995). Based on the Permian and Early Mesozoic facies boundaries, Majoros (1980), Kovács (1982), Kázmér (1984), and Kázmér and Kovács (1985) postulated an approximately $500 \mathrm{~km}$-long dextral displacement (tectonic escape) of the Transdanubian Range Unit along the PAL (Periadriatic Line) -BAL system.

Csontos et al. (1992) and Csontos and Nagymarosy (1998) interpreted the zone between the BAL and MHL as a large-scale transpressional zone along which the ALCAPA and the Tisia-Dacia terranes, rotating in opposite senses (Márton 1987), came into juxtaposition during the Late Oligocene-Early Miocene. Rotational reconstructions were proposed by Balla (1987a), Márton and Fodor (1995), Kováč et al. (1998), Csontos et al. (2002), and Kovács I. et al. (2007). 


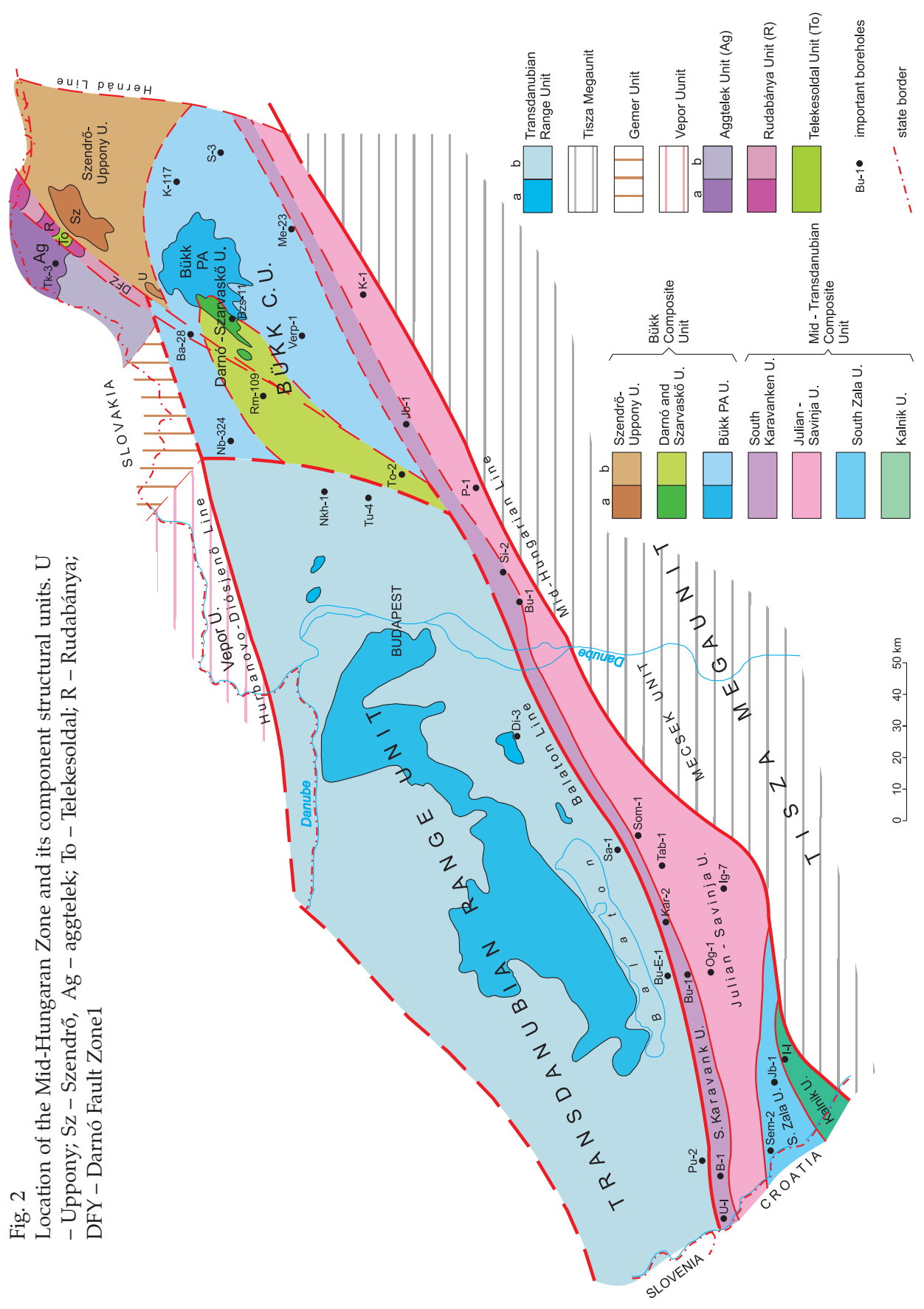

Central European Geology 53, 2010 
Csontos and Vörös (2004) considered the Mid-Hungarian Zone as a lateral shear belt and an overthrust zone of flysch nappes (Szolnok Flysch) between the ALCAPA and Tisza-Dacia Terranes that experienced NW-SE shortening and NE-SW elongation synchronously during the Tertiary.

According to Schmid et al. (2008) the Mid-Hungarian Fault Zone is a substantial Miocene dislocation zone which includes "Adria-derived thrust sheets", i.e. the Zagorje-Mid-Transdanubian Unit and the area of Bükk Mts, but without the Uppony and Szendrô Units that were assigned by them to the Inner West Carpathians.

\section{Tectonostratigraphic units of the Mid-Hungarian Zone}

The area between the BAL and the MHL is made up of slices of South Alpine and Dinaridic origin, mostly hidden beneath the Tertiary cover. We propose the term Mid-Hungarian Zone for this area although we know that a similar term (Mid-Hungarian Fault Zone) was previously used in a somewhat different sense (Balla 1984; Csontos et al. 1992; Fodor et al. 1998; Csontos and Vörös 2004; Schmid et al. 2008).

The Mid-Hungarian Zone is clearly definable in the area west of the Danube (Transdanubia); it is an approximately $30 \mathrm{~km}$-wide zone between two major lineaments (BAL and MHL). The Transdanubian Range Unit occurs north of the BAL, whereas the Mecsek Unit of the Tisza Mega-unit occurs south of the MHL (Figs 1 and 2). East of the Danube, however, this simple definition is no longer possible. The MHL (actually the northern boundary of the Tisza Mega-unit) can be followed north-eastward as far as the Tisza River, although this assumption is supported by only a few borehole data. Further north-eastward the pre-Tertiary basement is unknown due to an extraordinarily thick Neogene volcanic complex that has not been penetrated by boreholes. The continuation of the BAL further to the northeast is even more uncertain. South of Lake Balaton the BAL is well defined; it runs between the metamorphic Paleozoic formations of the Transdanubian Range Unit in the north and the Triassic carbonates of the MidHungarian Zone in the south (Mid-Transdanubian Unit). In contrast, further northeast there are mostly Triassic platform carbonates on both sides of the line, rendering its recognition difficult. Accordingly, east of the Danube, the position of the southeastern structural boundary of the Transdanubian Range is not precisely known. The Bükk Composite Unit occurs northeast of the Transdanubian Range and the Mid-Transdanubian Units, which are hardly separable in this area. Moreover, the exact position and nature of the structural contact between the Transdanubian Range/Mid-Transdanubian Units and Bükk Unit is not known either. As a matter of fact, in North Hungary the Bükk Composite Unit, including the overthrusted Mónosbél, Szarvaskő and Darnó Nappes, is located north of the Tisza Mega-unit, between the MHL and the Diósjenó (=Hurbanovo) Line (Fig. 2). The latter is also the northern boundary of 
the Transdanubian Range Unit further to the west. Since these units show a number of common features with elements of the Mid-Transdanubian Unit, we believe that they also belong to the Mid-Hungarian Zone. The Mónosbél, Darnó, and Szarvaskő Units are dispersed elements of the Neotethys ophiolite mélange. Accordingly these elements can also be considered as parts of the Mid-Hungarian Zone, since they participated in the large-scale Tertiary displacement, together with the previously-mentioned elements.

\section{Mid-Transdanubian Composite Unit}

In the northern part of the Mid-Transdanubian Composite Unit nonmetamorphosed Permian and Triassic formations form the pre-Tertiary basement, showing affinity with the eastern part of the Southern Alps (Carnic Alps and South Karavanks) (Bérczi-Makk et al. 1993; Rálisch-Felgenhauer 1998). The slightly metamorphosed Permian, Triassic and Jurassic formations in the southwestern part of the unit and the ophiolite mélange encountered in a few wells in a narrow strip along the southern structural contact of the unit (Árkai et al. 1991; Bérczi-Makk et al. 1993; Rálisch-Felgenhauer 1998) might be the continuation of some complexes exposed in the Medvednica and Kalnik Mts in the Hrvatsko Zagorje area (Croatia), considered as the northwesternmost part of the Inner Dinarides (Haas et al. 2000).

Elements showing affinity with the Carnic Alps and South Karavanks South Karavank Unit

In the westernmost part of Hungary, near the Slovenian border and south of the BAL, an approximately $700 \mathrm{~m}$-thick Permian sequence was penetrated in well Ujfalu (U-I in Fig. 2). The lower part of this succession is made up of fine-grained siliciclastics with limestone intercalations, similar to the Košna Formation of Velebits (Croatia); Bérczi-Makk and Kochansky-Devidé (1981). The limestone beds are rich in foraminifera and calcareous algae. The foraminiferal fauna (Darvasites-Palaeofusulina assemblage) can be correlated with that of the Lower Permian Trogkofel Limestone of the South Karavanks and the Carnic Alps (Bérczi-Makk and Kochansky-Devidé 1981; Bérczi-Makk et al. 1993). Similar siliciclastics were reported from Vitanje, Konjiška Gora, Boc, Zetale (eastern Slovenia) and Ravna Gora (western Croatia) containing limestone clasts with "Trogkofel-type" fossils (Bérczi-Makk and Kochansky-Devidé 1981). The Lower Permian succession is overlain by sandstone followed by shallow marine dolomite, Middle to Late Permian in age. There is an approximately $5-10 \mathrm{~km}$ wide zone along the BAL where similar Lower Permian marine formations with a similar fossil assemblage were encountered in several wells. Similar sequences have been reported form wells at Karád (Kar-1, -2; Fig. 2) south of Lake Balaton (Bérczi-Makk 1988; Bérczi-Makk et al. 1993). 
A marine Upper Permian succession, mostly shallow marine carbonates (limestone and dolomite), was also found in cores east of the Danube (Sári, Si-2 and Bugyi, Bu-1; Fig. 2) (Bérczi-Makk 1978). However, the structural setting of this area could not be determined on the basis of the Upper Permian formations, due to the similar facies characteristics occurring in the Transdanubian Range, the Bükk and the Mid-Transdanubian Units.

Recently, a marine Lower Permian succession was reported from a hydrocarbon exploratory well further to the NE, near Jászberény (Jb-1 in Fig. 2), south of the Bükk Mts in North Hungary (Cserepes et al. 2008). This suggests the continuation of the band of Carnic Alps-South Karavanks relationships and, accordingly, of the Mid-Transdanubian Unit east of the Danube.

A great number of wells encountered Triassic formations in the South Karavank Unit, allowing the compilation of a generalized succession. The Lower Triassic is made up of lilac-coloured variegated shale that is overlain by an interval of alternating limestone, dolomite and shale, representing shallow ramp and lagoon facies. Shallow marine dolomite typifies the Anisian. Coeval platform and basin facies characterize the Ladinian to Carnian interval. Wetterstein-type limestone represents the platform facies. The basin facies is typified by cherty limestone, marl and volcanic tuff in several horizons in the Ladinian, and marl and siltstone in the Carnian. The Norian to Rhaetian is represented by Dachsteintype platform carbonates (Bérczi-Makk et al. 1993; Rálisch-Felgenhauer 1998).

The Triassic sequence of the Southern Karavanks is characterized by Werfentype Lower Triassic, shallow marine Anisian dolomite, coeval platform carbonates (Schlern and Conzen Dolomite) and basin facies consisting of marl with volcanic tuff (Wengen Fm.) in the Ladinian, marl, limestone and sandstone (Raibl Group) in the Carnian, and Hauptdolomit and Dachstein Limestone in the Norian to Rhaetian (Grad and Ogorelec 1980; Ramovš 1989; Gianolla et al. 1998; Cozzi 2000; Dozet 2000), very similar to what was encountered in the wells south of the BAL.

Based on the diagnostic Lower Permian marine facies and position of this narrow strip in the neighborhood of the PAL-BAL its derivation from the Carnic Alps and Southern Karavanks is well constrained; the features of the Triassic succession do not contradict this.

Marine Permian formations were also encountered south of the metamorphosed Paleozoic series forming the southern limb of the synform of the Transdanubian Range, in the southern foreland of the Velence Hills (Majoros 1980; Haas et al. 1986). However, in these sequences the Lower Permian marine deposits are missing. Continental red beds occur at the base of the Permian (corresponding to the Val Gardena or Gröden Fm.) that is overlain by evaporitic sabkha and dolomitic lagoon facies (corresponding to the Bellerophon Fm., Fiamazza facies) akin to that in the northeastern part of the Transdanubian Range (and also in the eastern Dolomites). Accordingly this area can be assigned to the Transdanubian Range Unit. 
Julian-Savinja Unit

South of the above-described narrow strip there is a relatively wide zone where, beneath a Tertiary cover, predominantly non-metamorphosed Triassic platform carbonates were encountered. However, there are only very limited data for a relatively large area, making the evaluation and correlation of this zone rather uncertain. Marine Upper Permian dolomite was found in a single well (Fülöp 1990) but this cannot be considered as a deterministic feature for the facies relations. No data exists for the Lower Triassic. The Middle and Upper Triassic is characterized by typical shallow ramp - platform facies, namely SteinalmWetterstein type and Dachstein type facies, respectively (Haas et al. 1988; BércziMakk et al. 1993).

This composite sequence has no real relevance in determining the facies relationships and the original setting of this segment. Continuous Middle to Upper Triassic platform succession, i.e. lack of basin facies, occurs everywhere in the core of platforms in the South Alpine-Dinaridic realm (see Bosselini 1984, 1991; Dimitrijević and Dimitrijević 1991; Gianolla et al. 1998). Most probably Permian-Triassic formations of the Julian Alps and Savinja Alps, respectively, continue eastward beneath the Tertiary cover. Displaced elements of these South Alpine units were probably encountered in the Mid-Hungarian Zone south of Lake Balaton. It is worth mentioning, however, that in the Julian Alps (and also in the Carnic Alps and Southern Karavanks) the Middle Triassic platform carbonates are predominantly dolomitized whereas in the Mid-Transdanubian area mostly limestone was found in the corresponding interval.

Elements showing affinity with the Medvednica and Kalnik Units

South Zala Unit

The Medvednica Unit is made up of low-grade metamorphic rocks which are exposed in the lower nappe of the Medvednica Mts (Tomljenović 2002) and were also found in some wells in the northeastern part of Croatia beneath Tertiary cover (Haas et al. 2000). In the Medvednica Mts the Silurian to Triassic (Norian) sedimentary and magmatic series (Pamić and Tomljenović 1998) was subjected to very low to low-grade metamorphism in the Cretaceous (110-80 Ma; Judik et al. 2006). The metamorphic alteration may have taken place at temperatures of 300 $410{ }^{\circ} \mathrm{C}$ and pressures of 3.5-4 kbar (Judik et al. 2006). In the Mid-Transdanubian area, the South Zala Unit, located south of the previously discussed nonmetamorphic units (Fig. 2), Upper Permian evaporitic carbonates, Triassic carbonates of basin and slope facies, and Middle Jurassic hemipelagic shale and volcanoclastics affected by low-grade metamorphism, also Cretaceous in age (93-97 Ma), were encountered (Balogh et al. 1990; Árkai et al. 1991; RálischFelgenhauer 1998). It cannot be excluded that the Medvednica and the South Zala Units are parts of a single tectonostratigraphic unit (Haas et al. 2000). 
Kalnik Unit

In Zagorje (Croatia) an ophiolite mélange complex considered to be the prolongation of the Vardar Zone was defined as the Kalnik Unit (Pamić 1997, 2000). Mountain Kalnik is made up predominantly of this mélange complex and there are also outcrops of it in the Medvednica and Ivanšćica Mts (Pamić 1997; Pamić and Tomljenović 1998; Babić et al. 2002; Tomljenović 2002; Tomljenović et al. 2008). The mélange complex contains smaller or larger blocks of basalt, gabbro, serpentinite, radiolarite, shale and limestone of varying age in a strongly tectonized shaly matrix. There is evidence for multiple redeposition of elements of the mélange complex (Babić et al. 2002; Tomljenović 2002). In the Medvednica and Kalnik Mts blocks of rift-type peperitic basaltoid rocks also occur (Palinkaš et al. 2008). Ladinian and Carnian to Norian radiolarian assemblages were found in radiolarian chert, in direct stratigraphic contact with pillow basalt (Halamić and Goričan 1995; Goričan et al. 2005) constraining a Middle to Late Triassic age of such blocks in the mélange. In the Medvednica Mts Bathonian to Callovian radiolarians were encountered in radiolarite beds intercalated into a polymict olistostrome (debrite) succession containing pebble-sized sandstone, siltstone, chert and basalt clasts and olistoliths in a shale matrix (Halamić et al. 1999). Parts of this Jurassic accretionary complex were redeposited in the Late Cretaceous due to intense tectonic movements, and again in the Oligocene, as is confirmed by Cretaceous and Paleogene microfossils found in the matrix in the Medvednica Mts (Pamić and Tomljenović 1998). Detailed studies usually revealed only diagenetic, rarely anchizonal, alteration of the matrix of the ophiolite complex at $120-260{ }^{\circ} \mathrm{C}$ in the Medvednica Mts (Judik et al. 2006; 2008).

In a few hydrocarbon exploratory wells (Inke I-I in Fig. 2) at the southernmost part of the Mid-Transdanubian Unit a very low-grade metamorphic complex containing fragments of volcanites, serpentinite, limestone of shallow marine facies and deep-marine black shale and radiolarite of Ladinian and Carnian age were encountered (Kozur in Haas et al. 1985; Dosztály 1994). These were assigned to the mélange of the Kalnik Unit (Józsa in Harangi et al. 1996; RálischFelgenhauer 1998; Haas et al. 2000).

\section{Bükk Composite Unit}

The Bükk Composite Unit is made up of the Bükk Unit s.s., and overlying nappes, namely the Mónosbél Nappe consisting of sedimentary formations and the Szarvaskő Nappe containing magmatic rocks intruded into siliciclastics. This structural setting observed in the Bükk Mts continues westward in the Darnó area and in the pre-Tertiary basement of the Mátra Mts (Fig. 2), although in that area the Mónosbél Nappe is overlain by the Darnó Nappe consisting mostly of igneous rocks. Paleozoic series subject to Mid-Cretaceous low grade metamorphism, which are exposed north and northeast of the Bükk Mts (Uppony Hills, Szendrô Hills), are also assigned to the Bükk Composite Unit on 
the basis of their facies characteristics ("Bükkium" - Kovács and Péró 1983); however, they show opposing structural vergency. In terms of characteristics and age of their metamorphism, a similarity with the metamorphic complex of the Medvednica Mts was pointed out (Judik et al. 2006).

Bükk Unit s.s.

The Bükk Unit s.s. ( Nagyfennsík Parautochthonous; Csontos 1999, 2000) is made up of Upper Paleozoic to Jurassic formations which were subjected to diagenetic to low-grade metamorphism in the Early Cretaceous. In the Bükk Mts Middle Carboniferous fine siliciclastic turbidites, corresponding to the "Variscan flysch stage", comprise the oldest formation exposed. This is overlain by late Middle to Late Carboniferous shallow marine shale, sandstone, and shallow marine fossiliferous limestone. After an interval of subaerial exposure, a new depositional cycle was initiated in the Middle Permian with terrestrial sandstone overlain by evaporitic tidal flat deposits, lagoonal and shallow ramp carbonates of the Late Permian (Fülöp 1994). The Permian-Triassic boundary is within a continuous marine succession, and fine siliciclastics and carbonates of shallow ramp facies characterize the Lower Triassic. Extensional tectonics in the MidTriassic led to formation of platforms and basins and accordingly accumulation of coeval platform carbonate and basinal carbonate series (Velledits 2000; Csontos 2000; Pelikán 2005) accompanied by intense andesitic and then basaltic volcanism (Szoldán 1990; Harangi et al. 1996). The evolution of carbonate platforms came to the end during the Late Triassic and in the Early Jurassic basins only condensed pelagic carbonates were deposited, locally and episodically. Both the platform carbonates and the basin deposits were covered by radiolarite, sometime within the rather wide Bajocian to Oxfordian age-range (Csontos et al. 1991; Pelikán 2005, Haas et al. in press). This is overlain by a dark gray siliciclastic turbidite succession, probably of Middle or Late Jurassic age, representing the "Eohellenic flysch stage" (Papanikolau et al. 2006).

The Bükk Unit was subjected to anchizonal to low-epizonal metamorphism at 200-350 ㄷ, 1.5-3, locally 5, Kbar (Árkai 1983), and SE-vergent folding (Csontos 1999). Ka-Ar measurements on illite-muscovite of Upper Paleozoic metasediments yielded ages of 111-147 Ma, whereas the zircon fission track data scatter between 111 and $167 \mathrm{Ma}$; the youngest age value may in this case provide the minimum age of metamorphism (Árkai et al. 1995). Another tectonometamorphic event was recognized at 77 to $82 \mathrm{Ma}$ (K-mica, K-Ar, and zircon fission track; Árkai et al. 1995) resulting in ductile deformation (Csontos 1999).

The marine Late Paleozoic to Triassic succession of the Bükk Unit shows striking affinity with corresponding successions in the Carnic Alps - South Karavanks (Ebner et al. 1991), Julian Alps, Zagorje-Mid-Transdanubian Unit (Haas et al. 2000) and Sana-Una and Jadar blocks of the Dinarides (Pesic et al. 1986; Protic et al. 2000; Filipovic et al. 2003). In the Late Paleozoic these domains 
belonged to a deeper internal part of the large marginal bay of the Paleotethys Ocean (Carnic-Dinaridic Microplate - Vai 1994, 1998, 2003). During the Late Carboniferous to the Mid-Triassic interval, sediment deposition took place on a shallow marginal ramp. Westward opening of the Neotethys resulted in the development of an articulated bottom topography, i.e. the formation of platforms and basins on the margin of the newly-formed ocean. In the Early Jurassic progressing of ocean opening led to attenuation of the continental margin and enhanced subsidence that resulted in the establishment of deep-marine conditions, giving rise to deposition of radiolarite and distal siliciclastic turbidites in the Middle Jurassic.

\section{Uppony and Szendrő Units}

The Uppony Unit is located immediately to the north of the Bükk Unit s.s., but shows an opposite (north-western) structural vergency. Its sequence begins with Upper Ordovician sandstone, followed by a lydite-shale succession of deepmarine facies, with associated Silurian?-Devonian basic volcanics. The Middle Devonian to Lower Carboniferous is represented by platform carbonates and overlying basinal carbonates, which are followed by an alternation of uppermost Lower to lowermost Upper Carboniferous basinal carbonates and shale, coeval with the flysch-type turbiditic succession of the Szendrô Unit, but lacking the characteristics of flysch (Ebner et al. 1998). The unit was affected by a Cretaceous $(118 \pm 14 \mathrm{Ma})$ metamorphism corresponding to the boundary of the anchi/ epizone (2.5 Kbar, $350{ }^{\circ} \mathrm{C}$; Árkai et al. 1995).

The Szendró Unit, which also has a NW-vergent structure, is located NE of the Bükk Unit s.s. and the Uppony Unit. Its oldest formation is a ?Silurian to Lower Devonian lydite - finely siliciclastic (phyllite, metasandstone) formation, followed by Middle Devonian to Lower Carboniferous carbonates of platform and basin facies, respectively (Kovács 1992; Koroknai et al. 2001b). A flysch-type turbiditic siliciclastic succession, containing limestone olistostromes in its lower part, terminates the preserved succession (Ebner et al. 1998). The higher part of the latter formation likely corresponds to the oldest known formation of the Bükk Unit s.s. (Ebner et al. 1991), although the two units show opposite structural vergencies. The unit was affected by a Cretaceous (108 $\pm 8 \mathrm{Ma})$ low-grade metamorphism (400-450 ${ }^{\circ} \mathrm{C}$, 3 Kbar; Árkai et al. 1995). The DevonianCarboniferous lithofacies and the Cretaceous metamorphism of the Szendrô Unit corresponds to the Medvednica Metamorphic Complex of the similarly NWvergent Medvednica Mts in the Zagorje region (Judik et al. 2006; 2008). 
Dispersed elements of the Neotethys subduction related complexes

in the Bükk-Darnó area

The Bükk Unit s.s. is overthrusted from the NW (according to present-day coordinates) by the Mónosbél Unit (Mónosbél Nappe) (Csontos 1999). Erosional remnants of this nappe occur in the western part of the Bükk Mts and equivalents of this nappe were also encountered in the basement of the Mátra Mts, west of the Bükk Mts. The Mónosbél Unit is made up of Bajocian to Oxfordian (?) deep-marine siliciclastics (mostly shale), carbonates and siliceous sediments with intercalations of olistostrome beds, which contain very heterogeneous clasts that were transported via gravity mass movements into the basin. In the olistostrome beds, along with fragments of acidic, intermediate and basic magmatites, phyllite, siltstone, sandstone, pelagic carbonates and radiolarite, and lithoclasts of redeposited carbonates containing grains of shallow platform origin (ooids, oncoids, skeletal fragments of shallow marine biota) are common. Large blocks (olistoliths), mostly of platform-derived ("Bükkzsérctype") limestone of Bajocian to Bathonian age, also occur in the Mónosbél Unit.

Gravity deposits of the Mónosbél Unit are also exposed in the Darnó area and in the ore exploration wells at Recsk, Mátra Mts, respectively (Kovács et al. 2008). In a borehole (Recsk, Rm-109) drilled near Kékes Peak (Mátra Mts) Bajocian platform-derived redeposited carbonates, more proximal than those in the Bükk Mts, were encountered in a remarkable thickness (Haas et al. 2006).

The lithologically very heterogeneous Mónosbél Complex was deposited during the Bajocian to Callovian (Oxfordian?) interval under deep-marine conditions, where large amounts of gravity deposits (olistostromes, olistoliths) were accumulated, showing an upward-coarsening trend.

Andesite breccia horizons occurring in the lower part of the Mónosbél Complex of Bathonian to Early Callovian age (Pelikán and Dosztály 2000; Haas et al. 2006). In the higher part of the Mónosbél Complex there is a wide spectrum of the volcanic material along with carbonate lithoclasts of various shallow and deep-marine facies, and small amounts of metamorphic components (of a higher metamorphic grade than the matrix). These polymict olistostromes imply compressional tectonics, imbrication, and onset of nappe stacking.

In the upper part of the Mónosbél Complex olistostromes consisting mostly of fragments of platform carbonates and large platform limestone ("Bükkzsérctype") blocks occur. It is plausible that the platform-derived carbonate sediment was affected by cementation prior to disintegration and redeposition. However, the fact that along with the very common oolitic limestone clasts, individual ooid grains and bioclasts of platform and foreslope origin also occur in the olistostromes, imply that unconsolidated shallow-marine sediments were also present in the source area of the gravity mass movements.

In the area of the Bükk Mts the Middle Jurassic platform-derived, redeposited ("Bükkzsérc-type") limestone is a significant component of the olistostrome beds, and olistolites of this type of carbonates are also typical. This is of critical value 
from the point of view of the interpretation, providing data for the primary carbonate factory, the environment of secondary deposition, the postdepositional diagenetic conditions and also the age of these processes; even the source area can be determined with high confidence. Based on foraminifera a Bajocian to Bathonian age was determined (Haas et al. 2006); the carbonate grains were formed on a carbonate platform and redeposited penecontemporaneously, prior to cementation of grains. In a wider region of the northwestern end of the Neotethys the carbonate platforms were drowned at the end of the Triassic (in the Northern Calcareous Alps and West Carpathians) or by the late Early Jurassic (in the area of the Trento Plateau and Julian Alps). The huge Adriatic-Dinaridic Carbonate Platform (ADCP) was the only place in the region where the platform conditions continued during the Middle and Late Jurassic and even in the Cretaceous, although the extent of the platform changed (Tilšjar et al. 2002). Consequently the ADCP was the only significant active shallowmarine carbonate factory in the Middle to early Late Jurassic which may have supplied the ambient basins.

Coeval with the opening of the westernmost sector of Neotethys, an extensional trough system formed. The Slovenian Trough, which separated the block of the Julian Alps from the ADCP (Buser 1989, 1996), was a part of this system. However, development of similar troughs may have caused the dismembering of the Bükk, Sana-Una and Jadar Blocks from the ADCP. All along the margin of these troughs platform-derived, mostly oolitic limestone was deposited in the Early and Middle Jurassic, mainly during the Late Bajocian to Bathonian highstand platform progradational interval, interfingering with basin facies farther from the platform.

Redeposited Jurassic oolitic limestone and carbonate lithoclastic slope deposits were reported from the Slovenian Trough (Rožič and Popit 2006), the Zumberak Mts of Croatia (Bucković et al. 2004; Bucković 2006), and also from the Pre-Karst and Bosnian Flysch Zone in Hercegovina and Montenegro (Dragicević and Velić 2002). It cannot be determined which part of the hundreds of kilometers-long platform foreslope was the source area of the clasts of olistostromes and large blocks in the Mónosbél Unit, but the northwestern segment is the most realistic candidate.

The Mónosbél Unit is overthrusted from the NW by the Szarvaskő Unit (Szarvaskő Nappe) in the western part of the Bükk Mts (Balla 1983; 1987b; Csontos 1999). Fine mid-Jurassic siliciclastics with intruded gabbros and extruded basalt and basalt lava rocks of the Szarvaskő Unit were formed in a backarc or a marginal oceanic basin (Balla 1983; Harangi et al. 1996). West of the Bükk, in the Darnó area and also in the basement of the Mátra Mts, the Darnó Unit occurs above the Mónosbél Unit. The Darnó Unit is made up of Mid-Triassic peperitic and amygdaloidal basalt, similar to that in the Kalnik Unit (Palinkaš et al. 2008; Kiss et al. 2008) formed in the rift zone during the incipient stage of the opening of the westernmost sector of the Neotethys Ocean (Kovács et al. 2010), and of 
Mid-Jurassic basalt similar to that of the Szarvaskó Unit. The Darnó Unit represents the northwesternmost occurrence of this Triassic peperitic facies in the Neotethyan domain (Kovács et al. 2010). Accordingly these predominantly magmatic complexes represent various evolutionary stages and various sectors of the Neotethys Ocean, including its marginal and subduction-related backark basins.

As opposed to former considerations (e.g. Kovács 1984; Csontos 1988; Kozur 1991) the Darnó Unit, forming part of the S-vergent Dinaridic Bükk nappe system, cannot be structurally equivalent to the Meliata Unit (s.s.) forming part of the N-vergent Austroalpine-Gemeric nappe system, although they were both derived from the northwestern end of the Neotethys (cf. Haas and Kovács 2001; Kovács et al. 2008).

In the Dinarides *Fig. 1), ophiolite mélange complexes comparable to those in the Bükk-Darnó area occur in the Dinaridic Ophiolite Belt (Dimitrijević et al. 2003). In the DOB the ophiolite mélange contains fragments of obducted ophiolites (lherzolite), Triassic and Jurassic limestone olistoliths, and polymict olistostromes containing clasts of Middle Triassic to Upper Jurassic radiolarian chert, greywacke, basalt, gabbro, ultramafic rocks, granite along with Triassic carbonates (Middle-Upper Triassic platform carbonates and basin facies - Bulog, Hallstatt-, Bódvalenke-type) and Jurassic redeposited carbonates in a Jurassic argillaceous, silty matrix (Karamata et al. 2000; Pamić et al. 2002; Karamata 2006). According to radiometric dating (K/Ar) the age of metamorphism of the sole below the obducted ultramafic slices is between 181 to 157 Ma (Karamata 2006). The mélange was locally covered by shallow marine deposits of Tithonian to Early Cretaceous age.

In the Vardar Zone (Main Vardar Zone - Karamata 2006) the Jurassic olistostromes contain clasts of greywacke, radiolarian chert, basalt, gabbro, and ultramafics in a siltstone matrix (Karamata et al. 2000). Based on K-Ar dating of amphibolite of the metamorphic sole, closure of the Main Vardar Zone basin began between 182 and 187 Ma (Karamata 2006). The ophiolite mélange was overlain by Tithonian reef limestone, suggesting the end of the active closure by this time.

\section{Neotethyan mélange complexes in the area of Rudabánya Hills, Aggtelek Karst and Slovak Karst}

\section{Rudabánya Hills}

The wedge-like, narrow strip of the Rudabánya Hills is located within the strongly tectonized Darnó Fault Zone (Fig. 2). It is made up of the anchi/epizonal metamorphosed Martonyi (formerly Torna) Unit, the non-metamorphosed Bódva Unit, and the low-grade metamorphosed Telekesoldal Unit (Less 2000; Kövér et al. 2008). The latter likely represents part of a Middle to Late Jurassic subduction-related sedimentary complex (probably inter-arc/back-arc basin 
setting) containing black shale, locally with sandstone turbidites and olistoliths, as well as limestone-rhyolite olistostromes and acidic subvolcanic bodies (olistoliths) (Kovács 1988). The grade of metamorphism is at the boundary between anchi and epizone; a range of 120-140 Ma was measured for age of peak metamorphism and $90 \mathrm{Ma}$ for nappe overthrusting (Kövér et al. 2009). The Martonyi Unit is characterized by Middle-Upper Triassic basinal limestone. It significantly differs from the Turna Unit s.s. due to the lack of any basic volcanism, which occurs in the type locality of the latter (Turna Valley, Slovakia; Mello et al. 1997). The Bódva Unit is made up of Lower Triassic shallow-marine siliciclastics and marl, early Middle Triassic ramp carbonates (Gutenstein, Steinalm), that is overlain by deep water carbonates (Bódvalenke Limestone, followed by Hallstatt Limestone). The Middle - Upper Anisian to Upper Carnian Bódvalenke Limestone represents a transitional facies between red, pelagic limestone and red radiolarite (Kovács 2010). Blocks of similar limestone (Bódvalenke-type limestone) are common in the ophiolite mélange of the Dinaridic Ophiolite Belt and Maliac Zone of the Hellenides (Kovács et al. 2010). In this context it is worth mentioning that the northwesternmost occurrence of this facies in the Neotethys domain is found in the Rudabánya Mts (Kovács 2010); it is not known to occur in the West Carpathians and Eastern Alps.

\section{Aggtelek Karst}

Tectonically incorporated slices of serpentinite, gabbro and basalt of MORBaffinity (Tornakápolna Unit) (Réti 1985; Horváth 2000) occur in Upper Permian evaporites forming the sole of the Aggtelek and (?)Bódva Units. In the Tornakápolna-3 (Tk-3 in Fig. 2) borehole dark gray to black siliceous shale and silicified sandstone of supposed Jurassic age, similar to those of the Darnó Unit, were found between two large serpentinite slices of lherzolitic origin (Józsa et al. 1996; Kovács et al. in Haas 2004). In a single red radiolarite-mudstone intercalation in pillow basalts, penetrated by the same borehole, Ladinian radiolarians were found (Kozur and Réti 1986; Dosztály and Józsa 1992).

The Aggtelek Unit is located NW and N of the Rudabánya Mts; it is part of the Silica Nappe s.s. (sensu Kozur and Mock 1973). The southeastward facing Aggtelek reef occurs in the NW part of the unit; it is the oldest (Upper Anisian to lowermost Ladinian) platform margin reef of the Alpine Triassic (Velledits et al. 2008) The eastern part of the unit is characterized by a southward-facing Carnian Wetterstein carbonate platform (reefal facies in the $\mathrm{S}$ and lagoonal facies in the $\mathrm{N}$ ) and Ladinian to Carnian slope facies in its southern foreland (Kovács 1997; Péró et al. 2002, 2003). Both the platform carbonates and the slope deposits are covered by Upper Carnian to Norian Hallstatt Limestone. 


\section{Slovak Karst}

The Meliata Unit in SE Slovakia is also a displaced fragment of the Middle to Late Jurassic (Upper Callovian to Lower Oxfordian - Kozur and Mock 1985; Vozárová and Vozár 1992; Kozur et al. 1996) subduction-related Neotethyan sedimentary complexes. It is made up of olistostromes with larger olistoliths in a black shale and radiolarite matrix. Among the olistoliths Lower to Middle Anisian limestone, Ladinian radiolarite, Ladinian basalt (in Jaklovce), Upper Triassic basinal limestone, and Jurassic deep-marine deposits and volcanic rocks (predominantly basalt) were found (Kozur and Mock 1973; Vozárová and Vozár 1992; Mello et al. 1995; Kozur et al. 1996; Mock et al. 1998). The Meliata Unit is overthrusted by the Silica Nappe and accordingly a number of tectonically disintegrated blocks of the Meliata Unit, including MORB-type basalt bodies, were emplaced into the Permian-Lower Triassic evaporitic sole of the overriding nappe (Mello et al. 1997).

\section{Discussion}

On the northeastern continuation of the Periadriatic-Balaton Line

Whereas the south-western part of the Mid-Hungarian Zone is well defined by the bordering MHL to the SE (that forms the northwestern boundary of the Tisza Mega-unit) and the PAL-BAL to the NW (see Fig. 1), which stretches from the Zagorje region in NW Croatia (Kalnik, Medvednica and Ivanšćica Mts) to the Danube River, its northeastward continuation in the Bükk-Gemer area (cf. Less and Mello 2004) is rather problematic. This zone was named the "Zagorje-BükkMeliata Zone" by Pamic et al. (2002) and Pamic (2003). South of the Bükk Mts the continuation of the MHL is still defined by borehole data as far as east of the Tisza River (cf. Fig. 2). The direct northeastward continuation of the BAL, however, is rather ambiguous. The prominent Darnó Fault Zone (DFZ) was considered its continuation by a number of authors (Szalai 1961; Dank and Bodzay 1971; Wein 1978; Channel et al. 1979; Ustaszewski et al. 2008). However, elements of the Bükk Composite Unit (at least the mélange complex of the Mónosbél Unit) continue NW of the DFZ, in the pre-Tertiary basement of the Recsk Paleogene volcanic complex (Haas and Kovács 2001; Kovács et al. 2008), which represents the northeasternmost-known occurrence of the Periadriatic magmatic chain (Kovács et al. 2007; Földessy et al. 2008; Less et al. 2008). Accordingly the tectonic boundary between the Bükk Composite Unit and the Transdanubian Range Unit can be considered as the continuation of the BAL. This poorly defined fault zone running somewhere in the Zagyva Trough (see Haas et al. 2010) is dislocated by the Hurbanovo-Diósjenó Fault. North of the Hurbanovo-Diósjenó Fault the northeastern continuation of the Darnó Fault Zone is the western boundary of the Bükk Composite Unit (Uppony and Szendró Hills), whereas it is bordered by the Hernad Fault eastward. 
Is there any Neotethyan suture zone in the Circum-Pannonian region?

Mid-Hungarian Zone versus "Meliata-Hallstatt Suture"

The suture zones of the Neotethys Ocean can be continuously traced in the Alpine-Himalayan orogenic belt from SE Asia and Indonesia up to Serbia and Bosnia (Robertson and Karamata 1994; Robertson 2004; Robertson et al. 2009) over a length of more than 12,000 km (Robertson 2007), represented by huge obducted ophiolite mélanges, exposed at surface practically continuously over an extent of hundreds or thousands of $\mathrm{km}^{2}$. The northwesternmost completely preserved cross-section of this closed ocean can be seen just south of the Pannonian Basin, in the Bosnian-Serbian sector (cf. Dimitrijević 2001; Karamata 2006, and references therein). Further northward, northwestward, and northeastward, in the Circum-Pannonian region, only small, dispersed remnants of these Neotethyan accretionary complexes occur, of a few $\mathrm{km}^{2}$ (but sometimes even a few $\mathrm{m}^{2}$ ) surface or subsurface extent. They have been dispersed (thus representing typically small "disrupted terranes" in the sense of Howell (1989) by late Mesozoic to Tertiary (pre-Middle Miocene) nappe movements and sizeable strike-slip displacements.

The Mid-Hungarian Zone represents a prominent transpressional zone in the Circum-Pannonian region, where displaced Dinaridic and South Alpine elements were encountered in wells over a distance of $400-500 \mathrm{~km}$ up to the Bükk Mts, where remnants of Neotethyan accretionary complexes are visible in a few $\mathrm{km}^{2}$ large surface extent in the Bükk (Szarvaskő) - Darnó area. Nevertheless, this zone can hardly be interpreted as an in situ "suture zone" (see above).

On the other hand, a "Meliata-Hallstatt suture zone" was supposed by several authors to run along the northern border of the Transdanubian Range Unit (i.e. along the Hurbanovo-Diósjenó Line); further westward it continues along the southern margin of the Northern Calcareous Alps up to the Salzburg region (Schweigl and Neubauer 1997; Plašienka et al. 1997; Kováč and Plašienka 2002; Csontos and Vörös 2004).

Neotethyan remnants (some ophiolite and radiolarite) are known in the northernmost part of the Gemer-Bükk area, related to the basement of the Stratena Nappe (Havrila and Ozvoldová 1996; Mello et al. 1995, 2000). Further westward no real evidence of such remnants is known up to the southeastern corner of the NCA (Mürztal Alps; Mandl and Ondrejciková 1991, 1993; Kozur and Mostler 1992). Although Vojtko (2000) assigned a slightly metamorphosed evaporitic sequence at the base of the Murán nappe to the "Meliaticum", it can hardly be considered as proof for an oceanic remnant.

Detailed structural and facies analyses of Kovác P. and Havrila (1997) pointed out that the Ladinian platform carbonate units in the Hronic region (formerly classed among the "North Gemeric" units or "Spišcum" - Andrusov 1968; Mahel 1986) are parts of the Triassic platform (Wetterstein, Ramsau carbonates) and basin (Reifling Limestone) system of the Hronicum. In spite of these studies, Kováč M. and Plašienka (2002) and Csontos and Vörös (2004) still considered 
these "North Gemeric" units as the SE margin of the "Meliaticum". Accordingly they interpreted the paleogeographic position of the "Meliaticum" further northwestward. In the light of Havrila's results this paleographical assumption has lost any credibility.

Interpretation of geophysical data concerning to the Hurbanovo-Diósjenő Line is another problem in this context. Balla (1989) interpreted the marked magnetic anomaly along the line as "Meliatic" bodies. However, detailed petrological studies have proved that those cores which were mentioned by Balla as belong to the "Meliaticum" represent the continuation of the Southern Veporicum without any "Meliatic" relic (Koroknai et al. 2001a).

The Lower Cretaceous Gerecse Flysch occurs south of the Hurbanovo Line and contains large amounts of sand-sized ophiolite detritus; it is considered to have been displaced from the southern neighborhood of the Rossfeld flysch basin near Salzburg in the NCA (Kázmér and Kovács 1985; Sztanó 1990; Császár and Árgyelán 1994). Thus it cannot provide unambiguous evidence of an oceanic domain lying just to the north of the present Hurbanovo Line.

All these facts provide arguments against a continuously preserved "MeliataHallstatt suture" stretching from the Gemer area to the southern part of the NCA. Indeed we can speak of small dispersed Neotethyan remnants along this strike, rather than of a continuous "zone". The strike-slip dispersion of these Eohellenic (Late Jurassic) elements, however, should have preceded the Middle-Late Cretaceous Paleoalpine nappe stacking, when they were incorporated into the north-vergent Austroalpine nappe pile (cf. Frank and Schlager 2006). The sinistral offset of the Upper Permian to Upper Triassic facies zones (especially the Hallstatt Limestone facies) occurring in NE Hungary (cf. Haas et al. 1995) may have been the result of the same process already taking place in the Late Jurassic, and not in the Tertiary as suggested in the first escape model by Kázmér and Kovács (1985). The track of the Jurassic strike-slip suggested by Frank and Schlager (2006), however, has been almost entirely obliterated by younger, Cretaceous and Tertiary movements. The Hurbanovo-Diósjenó Fault is considered to be a young, Tertiary sinistral strike-slip fault zone and kinematically cannot be the westward continuation of the Cretaceous thrust-faults in the Gemeric area (LubeníkMargecany and Rožňava Lines, respectively).

\section{Summary of the evolutionary history}

The elements of ALCAPA were subject to complex, multistage deformations and large-scale displacements. The Transdanubian Range Unit located north of the Periadriatic-Balaton Line was situated between the Southern Alps and Northern Calcareous Alps prior to the large-scale displacements (Majoros 1980; Kovács 1982; Kázmér and Kovács 1985; Haas and Budai 1995; Haas et al. 1995). Those blocks which occur at present between the PAL-BAL and the MHL, i.e. in the Mid-Hungarian Zone, belonged to the eastern sector of the Southern Alps 
and the western sector of the Dinarides. In the northern part of the Zagorje-MidTransdanubian Unit, displaced fragments of the Southern Alps (Carnic Alps, South Karavanks, Julian and Savinja Alps) occur. They were not affected by Alpine metamorphism. In the southern part of the Zagorje-Mid-Transdanubian Unit and also in the Bükk Unit, Alpine metamorphic complexes and Jurassic ophiolite mélange, showing affinity with the subduction-related Dinaridic ophiolite mélange complexes, are present. These elements may have been parts of a domain which accreted prior to the large-scale Tertiary displacements, and were dispersed as a result of these tectonic movements.

Mid-Triassic opening of the Neotethys Ocean resulted in the formation of early rift-type volcanics, remnants of which occur in the Kalnik and in the Darnó Units, respectively (Pamić and Tomljenović 1998; Haas and Kovács 2001; Palinkaš et al. 2008). Coeval extensional tectonics led to the formation of the Slovenian Troughs (Buser 1989, 1996; Šmuc and Car 2002) and other similar troughs which resulted in dismembering of the platform of the Julian Alps and other isolated platforms (among them the Bükk Platform) from the large Adriatic-Dinaridic Carbonate Platform (ADCP).

During the sea-floor spreading stage in the Late Triassic to Early Jurassic interval attenuation of the continental lithosphere took place along the oceanward outer shelf margin. It resulted in drowning of the dismembered platforms, while the platform development continued on the ADCP during the entire Jurassic (and also in the Cretaceous), supplying the ambient basins with carbonate grains.

Subduction of the Neotethys was initiated in the Middle Jurassic. The HellenicDinaridic ophiolites are classed mostly among the supra-subduction zone-type (SSZ) ophiolites (Robertson 2004; Robertson et al. 2009). The metamorphic soles formed by the underplating of cold oceanic crust to hot over-riding ophiolitic mantle were dated at 174-162 Ma by the Ar/Ar method and 174-147 by the K/Ar method in the Dinarides (Robertson et al. 2009). During subduction, in the frontal accretion zones gravitationally reworked material was accumulated in the trench or forearc basin, i.e. mélange complexes were formed. The subduction-related ophiolite mélange was subject to multiple displacements, restructuring and later reworking.

In the Dinaridic area ophiolite emplacement took place mostly in the Middle Jurassic to Early Cretaceous interval, although the western belt of the Vardar Zone remained an oceanic basin till the end of the Cretaceous (Usztasewski et al. 2008; Robertson et al. 2009). Development of the ADCP still continued coevally on the margin of the Adria Microplate. Collisions of the Adria Microplate with plate fragments occurred between the African and the European Plates, induced nappe stacking and related regional metamorphism in two stages in the late Early Cretaceous (110-120 Ma) and in the Late Cretaceous (75-95 Ma), respectively. These tectono-metamorphic events were also recognized in several units of the Mid-Hungarian Zone (Bükk Unit s.s., Uppony, Szendrő, Medvednica, 
South Zala) which may have been segments of Dinaridic (Internal Dinaridic) nappe stacks, probably formed in two stages during the Cretaceous. In general the ophiolite mélange complex was overthrusted upon the previous continental margin sequences, which is reflected in the usually lower-grade metamorphic alteration of the mélange. The non-metamorphosed units represent the uppermost member of the nappe stack.

Shearing, disintegration and squeezing out of the nappe stacks between the PAL-BAL and MHL may probably been have initiated in the latest Cretaceous, but the main stage of the transpressional displacement took place in the Paleogene to Early Miocene, when northeastern movement and counterclockwise rotation of the ALCAPA led to large-scale nappe stacking in the Outer Carpathian flysch basin (Balla 1987a; Royden 1988; Ratschbacher et al. 1991; Horváth 1993; Csontos and Nagymarosy 1998; Csontos et al. 1992; Fodor et al. 1999; Horváth et al. 2006; Kovács et al. 2007; Ustaszewski et al. 2008). The MidHungarian Zone was established at this time, in the final stage of accretion of the basement of the Pannonian Basin that subsequently began to develop.

\section{Acknowledgements}

The authors are indebted to S. Schmid (Basel) for his critical notes and comments on the former version of this paper that were taken into account in the revision of the present one. We are grateful to J. Vozár, A. Vozárova, and J. Mello (Bratislava), S. Karamata, M. Sudar and D. Jovanovic (Belgrade), and L. Palinkaš (Zagreb) for the consultations on important parts of the topic of the paper. The notes and suggestions of the referees Gy. Less and K. Brezsnyánszky were very useful for corrections made in the final stage of the edition of the paper. This work was supported by OTKA grant K61872.

\section{References}

Andrusov, D. 1968: Grundriss der Tektonik der Nördlichen Karpaten. - Vyd SAV, Bratislava, 188 p.

Árkai, P. 1983: Very low- and low-grade Alpine regional metamorphism of sedimentary rocks of the Meliata unit, Western Carpathians, Slovakia: implications of phyllosilicate characteristics. - Int. J. Earth Sci., 92, pp. 68-85.

Árkai, P., Cs. Lantai, I. Fórizs, Gy. Lelkes-Felváry 1991: Diagenesis and low-temperature metamorphism in a tectonic link between the Dinarides and the Western Carpathians: the basement of the Igal (central Hungary) Unit. - Acta Geol. Hung., 34, pp. 81-100.

Árkai, P., K. Balogh, I. Dunkl 1995: Timing of low-temperatute metamorphysm and cooling of the Paleozoic and Mesozoic formations of the Bükkium, innermost West Carpathians, Hungary. Geologische Rundschau, 84, pp. 334-344,

Babić, Lj., P.A. Hochuli, J. Zupanić 2002: The Jurassic ophiolite mélange in the NE Dinarides dating, internal structure and geotectonic implications. - Ecl. Geol. Helv., 95, pp. 263-275.

Balla, Z. 1983: Stratigraphy and tectonics of the Szarvaskő synform, Bükk Mts., North Hungary. Eötvös Loránd Geophysical Inst. Ann. Rep. on 1985, pp. 42-65.

Balla, Z. 1984: The Carpathian loop and the Pannonian basin: a kinematic analysis. - Geophysical Transactions, 30, pp. 313-353. 
Balla, Z. 1987a: Cenozoic paleomagnetic data for the Carpatho-Pannonian region in the light of Miocene rotation kinematics. - Tectonophysics, 139, pp. 67-98.

Balla, Z. 1987b: Tectonics of the Bükkian (North Hungary) Mesosoic and relations to the West Carpathians and Dinarids. - Acta Geol. Hung., 30, pp. 25-287.

Balla, Z. 1989: A Diósjenői diszlokációs öv újraértékelése. (Reinterpretation of the Diósjenó dislocation zone). - Geofiz. Int. Évi. Jel. 1987, pp. 45-57. (In Hungarian.)

Balogh, K. 1964: Die geologischen Bildungen des Bükk-Gebirges. - Ann. Inst. Geol. Hung., 48, pp. 245-719.

Balogh, K., Á. Kovách, Z. Pécskay, É. Svingor, P. Árkai 1990: Very low- and low-grade metamorphic rocks in the pre-Tertiary basement of the Drava Basin, SWE-Hungary, II: K-Ar and Rb-Sr isotope geochronologic data. - Acta Geol. Hung., 33, pp. 67-76.

Bérczi-Makk, A. 1978: Upper Permian marine sediments in hydrocarbon exploring borehole Sári-2, southeast of Budapest (Hungary). - Földt. Közl., 108, pp. 313-327.

Bérczi-Makk, A., V. Kochansky-Devidé 1981: Marin Lower and Middle Permian in the oil exploratory well Újfalu-1 (SW Hungary). - Acta Geol. Hung., 24, pp. 117-128.

Bércziné Makk, A. 1988: Study of Mesozoic (Triassic, Jurassic and Lower Cretacious) sedimentary formations of Transdanubia (South to the Balaton Line). - Manuscript in Hungarian, Archive of the Hungarian Oil and Gas Co.

Bérczi-Makk, A., J. Haas, E. Rálisch-Felgenhauer, A. Oravecz-Scheffer 1993: Upper Paleozoic-Mesozoic formations of the Mid-Transdanubian Unit and their relationships. - Acta Geol. Hung., 36, pp. 263-296.

Bosellini, A. 1984: Progradation geometries of carbonate platforms: examples from the Triassic of the Dolomites, Northern Italy. - Sedimentology, 31, pp. 1-24.

Bosellini, A. 1991: Geology of the Dolomites. An introduction. - Dolomieu Conference, Ortisei, 43 p.

Brezsnyánszky, K., J. Haas 1986: Main features of the Pre-tertiary basement of Hungary. Geologicky Zborník, Geol. Carp., 37, pp. 297-303.

Bucković, D. 2006: Jurassic limestones of Sošice, Zumberak Mt, Croatia; sedimentary signatures of the platform to basin transition. - Acta Geol. Hung., 49, pp. 355-371.

Bucković, D., B.C. Tešović, I. Gušic 2004: Late Jurassic paleoenvironmental evolution of the Western Dinarides (Croatia). - Geol. Carp., 55, pp. 3-18.

Buser, S. 1989: Development of the Dinaric and Julian carbonate platforms and the intermediate Slovenian basin (NW-Yugoslavia) - In: Carulli, G.B., F. Cucchi, C.P. Radrizzani (Eds): Evolution of the Karstic carbonate platforms. Mem. Soc. Geol. It., 40, pp. 313-320.

Buser, S. 1996: Geology of western Slovenia and its paleogeographic evolution. - In: Drobne, K., S. Gorican, B. Kotnik (Eds): The Role of Impact Processes in the Geological and Biological Evolution of Planet Earth. International workshop ZRC SAZU Ljubljana, pp. 111-123.

Channel, J.E.T., B. D'Argenio, F. Horváth 1979: Adria, the African promontory, in Mesozoic Mediterranean paleogeography. - Earth-Sci. Rev., 15, pp. 213-292.

Cozzi, A. 2000: Synsedimentary tensional features in Upper Triassic shallow-water platform carbonates of the Carnian Prealps (northern Italy) and their importance as palaeostress indicators. - Basin Research, 12, pp. 133-146.

Császár, G., G. Árgyelán 1994: Stratigraphic and micromineralogic investigations on Cretaceous Formations of the Gerecse Mountains, Hungary and their palaeogeographic implications. Cret. Res., 15, pp. 417-434.

Cserepes, M.B., P. Pelikán, A. Szekszárdi, A. Szuromi-Korecz 2008: A new Paleozoic occurrence in the Hungarian Paleogene Basin. - X. Conference of Mining, Metallurgy and Geology; Transylvanian Hung. Soc. Sci. Tech., Abstract, pp. 227-228.

Csontos, L. 1988: Étude géologique d'une portion des Carpathes Internes: le massif du Bükk (Stratigraphie, structures, métamorphisme et géodinamique). - Thése de Doctorat, Univiversité de Lille Flanders-Artois, $250 \mathrm{p}$.

Csontos, L. 1999: Structural outline of the Bükk Mts, North Hungary. - Föld. Közl., 129, pp. 95-131. (In Hungarian.) 
Csontos, L. 2000: Stratigraphic evaluation of the Bükk Mts., North Hungary - Föld. Közl., 130, pp. 611-653. (In Hungarian.)

Csontos, L., L. Dosztály, P. Pelikán 1991: Radiolarians from the Bükk Mts. - MÁFI Évi Jelentése 1989rôl, pp. 383-409. (In Hungarian.)

Csontos, L., A. Nagymarosy, F. Horváth, M. Kováč 1992: Tertiary evolution of the Intra-Carpathian area: a model. - Tectonophysics, 208, pp. 221-241.

Csontos, L., A. Nagymarosy 1998: The Mid-Hungarian line: a zone of repeated tectonic inversions. Tectonophysics, 297, pp. 57-71.

Csontos, L., L. Benkovics, F. Bergerat, J-L. Mansy, G. Wórum 2002: Tertiary deformation history from seismic section study and fault analysis in a former European Tethyan margin (the Mecsek-Villány area, SW Hungary). - Tectonophysics, 357, pp. 81-102.

Csontos, L., A. Vörös 2004: Mesozoic plate tectonic reconstruction of the Carpathian region. Palaeo. Palaeo. Palaeo., 210, pp. 1-56.

Dank, V., I. Bodzay 1971: Geohistorical background of the potential hydrocarbon reserves in Hungary. - Acta Min. Petr. Szeged., 20, pp. 57-70.

Dimitrijević, M.D. 1974: Dinaridi: jedan model na osnovama "Nove Globalne Tektonika". Metalogenija i koncepcije geotektonoskog razvoja Jugoslavije. - Rud. geol. fak. Univ. Beogradu, Kat. Ekon. Geol., pp. 119-151. (In Serbian.)

Dimitrijević, M.D. 1982: Dinarides: an outline of the tectonics. - Earth Evol. Sci., 2, pp. 4-23.

Dimitrijević, M.D. 2001: Dinarides and the Vardar Zone: a short review of the geology. - Acta Vulc., 13 , pp. $1-8$.

Dimitrijević, M.N., M.D. Dimitrijevic 1991: Triassic carbonate platform of the Drina-Ivanjica element (Dinarides). - Acta Geol. Hung., 34, pp. 15-44.

Dimitrijević, M.N., M.D. Dimitrijević, S. Karamata, M. Sudar, N. Gerzina, S. Kovács, L. Dosztály, Z. Gulácsi, Gy. Less, P. Pelikán 2003: Olistrotrome/mélanges - an overview of the problems and preliminary comparison of such formations in Yugoslavia and NE Hungary. - Slovak Geological Magazine, 9, pp. 3-21.

Dosztály, L. 1994: Mesozoic radiolarian investigation in North Hungary. - PhD Thesis, Eötvös Loránd Univ Budapest, 108 p. (In Hungarian.)

Dosztály, L., S. Józsa 1992: Geochronological evaluation of Mesozoic formations of Darnó Hill at Recsk on the basis of radiolarians and K-Ar age data. - Acta Geol. Hung., 35/4, pp. 371-393.

Dozet, S. 2000: Stratigraphy of the Verd oolitic limestone complex. - Rudarsko-metalurški zbornik, 47, pp. 245-238.

Dragicević, I., I. Velić 2002: The northeastern margin of the Adriatic Carbonate Platform. - Geologia Croatica, 55, pp. 185-232.

Ebner, F, S. Kovács, H.P. Schönlaub 1991: Das klassische Karbon in Österreich und Ungarn - ein Vergleich der Sedimentären fossilfürenden Vorkommen. - In: Lobitzer, H., G. Császár (Eds): Jubileumsschrift 20 Jahre Gelogische Zusammenarbeit Österreich - Ungarn. Teil 1, Wien, pp. 263-294.

Ebner, F, S. Kovács, H.P. Schönlaub 1998: Stratigraphic and facial correlation of the Szendró-Uppony Paleozoic (NE Hungary) with the Carnic Alps-South Karavanken Mts. and Graz Paleozoic (Southern Alps and Central Eastern Alps); some paleogeographic implications. - Acta Geol. Hung., 41, pp. 355-388.

Ebner, F, A. Vozárová, S. Kovács, H-G. Kräutner, B. Kristic, T. Szederkényi, D. Jamicic, D. Balen, M. Belak, M. Trajanova 2009: Devonin-Carboniferous pre-flysch and flysch environments in the Circum Pannonian Region. - Geol. Carp., 59, pp. 159-195.

Filipović, I., D. Jovanović, M. Sudar, P. Pelikán, S. Kovács, Gy. Less, K. Hips 2003: Comparison of the Variscan - Early Alpine evolution of the Jadar Block (NW Serbia) and "Bükkium" (NE Hungary) terranes; some paleogeographic implications. - Slovak Geological Magazine, 9, pp. 3-21.

Frank, W., W. Schlager 2006: Jurassic strike slip versus subduction in the Eastern Alps. - Int. J. Earth., 95, pp. 431-450. 
Fodor, L., B. Jelen, E. Márton, D. Skaberne, J. Car, M. Vrabec 1998: Miocene-Pliocene tectonic evolution of the Slovenian Periadriatic Fault: implications for Alpine-Carpathian extrusion model. - Tectonophysics, 17, pp. 690-709.

Fodor, L., L. Csontos, G. Bada, I. Györfi, L. Benkovics 1999: Tertiary tectonic evolution of the Pannonian Basin system and neighbouring orogens: a new synthesis of paleostress data. - In: Durand, B., L. Jolivet, F. Horváth, M. Séranne (Eds): The Mediterranean Basins: Tertiary Extension within the Alpine Orogen. Geol. Soc. London, Spec. Publ., 156, pp. 295-334.

Fülöp, J. 1990: Magyarország geológiája. Paleozoikum I. (Geology of Hungary, Paleozoic I. In Hungarian). - MÁFI, Budapest, 325 p.

Fülöp, J. 1994: Magyarország geológiája. Paleozoikum II. (Geology of Hungary, Paleozoic II. In Hungarian). - Akadémiai Kiadó, Budapest, 447 p.

Fülöp, J., K. Brezsnyánszky, J. Haas 1987: The new map of basin basement of Hungary. - Acta Geol. Hung., 30, pp. 3-29.

Földessy, J., T. Zelenka, K. Benedek, Z. Pécskay, F. Mádai 2008: The Recsk Paleogene magmatism in a regional context. - In: Földessy, J., É. Hartai (Eds): Recsk and Lahóca geology of the Paleogene Ore Complex - Geosciences, Miskolc University Press, pp. 7-20.

Gianolla, P., V. De Zanche, P. Mietto 1998: Triassic sequence stratigraphy in the Southern Alps (northern Italy): definition of sequences and basin evolution. - In: Mesozoic and Cenozoic sequence stratigraphy of European Basins. SEPM Spec. Publ., 60, pp. 719-747.

Goričan, Š., J. Halamić, T. Grasović, T. Kolar-Jurkovšek 2005: Stratigraphic evolution of Triassic arcbackarc system in northwestern Croatia. - Bull. Soc. Geol. France, 176, pp. 3-22.

Grad, K., B. Ogorelec 1980: Upper Permian, Scythian and Anisian rock in the Ziri area. - Geologia, 23, pp. 189-220.

Haas, J. (Ed) 2004: Magyarország geológiája. Triász (Geology of Hungary. Triassic; In Hungarian) Eötvös Univ Press Budapest 384 p.

Haas, J., F. Góczán, A. Oravecz-Scheffer, Á. Barabás-Stuhl, Gy. Majoros, A. Bérczi-Makk 1986: Permian Triassic boundary in Hungary. - Mem. Soc. Geol. It., 34, pp. 221-241.

Haas, J., E. Rálisch-Felgenhauer, A. Oravecz-Scheffer, E. Nagy, A. Bérczi-Makk 1988: Triassic key sections in the Mid-Transdanubian (Igal) structural zone. - Acta Geol. Hung., 31, pp. 3-17.

Haas, J., T. Budai 1995: Upper Permian-Triassic facies zones in the Transdanubian Range. - Riv. It. Pal. Strat., 101, pp. 249-266.

Haas, J., S. Kovács, L. Krystyn, R. Lein 1995: Significance of Late Permian-Triassic facies zones in terrane reconstructions in the Alpine North Pannonian domain. - Tectonophysics, 242, pp. $19-40$.

Haas, J., H. Kozur, Gy. Lelkes-Felvári 1985: Formations underwent very low-grade metamorphism in the Upper Triassic in the Inke-I borehole. - Manuscript, MÁFI Doc Centre. (In Hungarian.)

Haas, J., P. Mioč, J. Pamić, B. Tomljenović, P. Árkai, A. Bérczi-Makk, B. Koroknai, S. Kovács, E. Rálisch-Felgenhauer 2000: Complex structural pattern of the Alpine-Dinaridic-Pannonian triple junction. - Int. J. Earth. Sci., 89, pp. 377-389.

Haas, J., S. Kovács 2001: The Dinaridic-Alpine connection - as seen from Hungary. - Acta Geol. Hung., 44, pp. 345-362.

Haas, J., Á. Görög, S. Kovács, P. Ozsvárt, I. Matyók, P. Pelikán 2006: Displaced Jurassic foreslope and basin deposits of Dinaridic origin in Northeast Hungary. - Acta Geol. Hung., 49, pp. 125-163.

Haas, J., T. Budai, L. Csontos, L. Fodor, Gy. Konrád 2010: Magyarország pre-kainozoos földtani térképe 1: 500000 (Pre-Cenozoic geological map of Hungary, 1:500.000). - MÁFI, Budapest.

Haas, J., S. Kovács, P. Pelikán, Sz. Kövér, Á. Görög, P. Ozsvárt, S. Józsa, N. Németh (in press): A Neotethys-óceán akkréciós komplexumának maradványai Észak-Magyarországon (Remnants of the accretionary complex of the Neotethyan Ocean in Northern Hungary). - Földtani Közlöny.

Halamić, J., S. Goričan 1995: Triassic radiolarites from Mts. Kalnik and Medvednica (northwestern Croatia). - Geol. Croat., 48, pp. 129-146. 
Halamić, J., S. Goričan, D. Slovenec, T. Kolar-Jurkovsek 1999: A Middle Jurassic radiolarite-clastic succession from the Medvednica Mt. (NW Croatia). - Geol. Croat. 52, pp. $29-57$.

Harangi, Sz., Cs. Szabó, S. Józsa, Zs. Szoldán, E. Árva-Sós, M. Balla, I. Kubovics 1996: Mesozoic igneous suites in Hungary: implications for genesis and tectonic setting in (folytatás?).

Havrila, M., L. Ozvoldová 1996: Meliaticum in the Stratenská hornatina Hills. - Slov. Geol. Mag., Bratislava, 96, pp. 335-339.

Herak, M. 1986: A new concept of the geotectonics of the Dinarides. -Acta Geol.,16, pp. 1-42.

Heritsch, F. 1942: Korallen aus dem Perm des Bükk-Gebirges (Oberungarische Karpathen). - Anz. Akad. Wiss., Wien 79, pp. 13-15.

Heritsch, F. 1944: Permische Korallen aus dem Bükkgebirge in Ungarn. - Ann. Hist. Nat. Musei Hung., 37, pp. 48-63.

Horváth, F. 1993: Towards a mechanical model for the formation of the Pannonian basin. Tectonophysics, 226, pp. 333-357.

Horváth, F., G. Bada, P. Szafián, G. Tari, A. Ádám, S. Cloeting 2006: Formation and deformation of the Pannonian Basin: contraints from observational data. - In: Gee, D.G., R. Stephenson (Eds): European Lithosphere dynamics. Geol. Soc. London Memoir, 32, pp. 191-206.

Horváth, P. 2000: Metamorphic evolution of gabbroic rocks of the Bódva Valley ophiolite complex. Geol. Carp. 51, pp. 121-129.

Howell, D.G. 1989: Tectonics of Suspect Terranes. - Chapman and Hall, London-New York, 232 p.

Józsa, S., P. Horváth, P. Árkai 1996: Blue amphiboles from Meliata ophiolites in Northern Hungary. Acta Miner. Petr., 37, Suppl., 58.

Judik, K., K. Balogh, D. Tibljaš, P. Árkai 2006: New age data on low-temperature regional metamorphism of Mt. Medvednica (Croatia). - Acta Geol. Hung., 49, pp. 207-221.

Judik, K., G. Rantitsch, T.M. Rainer, P. Árkai, B. Tomljenović 2008: Alpine metamorphism of organic matter in metasedimentary rocks from Mt. Medvednica (Croatia). - Swiss. J. Geosci., 101, pp. 605-616.

Karamata, S. 2006: The geological development of the Balkan Peninsula related to the approach, collision and compression of Gondwanan and Eurasian units. - In: Robertson, A.H.F, D. Mountrakis (Eds): Tectonic Development of the Eastern Mediterranean Region, Geol Soc., London, Spec. Publ., 260, pp. 155-178.

Karamata, S., M.D. Dimitrijević, M.N. Dimitrijević, D. Milovanović 2000: A correlation of Ophiolitic belts and Oceanic realms of the Vardar Zone and the Dinarides. - In: Karamata, S., S. Janković (Eds): Proc. Int. Symp. "Geology and Metallogeny of the Dinarides and the Vardar Zone", Acad. Sci. Arts Repub. Srpska, Collect. Monogr., I, Dep. Nat., Math. Tech. Sci., 1, pp. 191-194.

Kázmér, M. 1984: Continental escape of the Bakony-Drauzug unit in the Paleogene. - Ált. Földt. Szemle, 20, pp. 55-102.

Kázmér, M., S. Kovács 1985: Permian-Paleogene paleogeography along the eastern part of the Insubric-Periadriatic Lineament system: evidence for continental escape of the Bakony-Drauzug. - Acta Geol. Hung., 28, pp. 71-84.

Kiss, G., F. Molnár, L.A. Palinkaš 2008: Volcanic facies and hydrothermal processes in Triassic pillow basalts from the Darnó Unit, NE Hungary. - Geol. Croat., 61, pp. 385-394.

Koroknai, B., P. Horváth, K. Balogh, I. Dunkl 2001a: Alpine metamorphic evolution and cooling history of the Veporic crystalline basement in Northern Hungary: new petrological and geochronological constraints. - Int. J. Earth Sci., 90, (spec issue), pp. 740-752.

Koroknai, B., P. Horváth, T. Németh 2001b: Chloritoid schist from the Uppony Mts. (NE Hungary): structural and mineralogical-petrological data on a new occurrence. - Acta Geol. Hung., 44/1, pp. 47-65.

Kováč, M., D. Plašienka 2002: Geological Structure of the Alpine-Carpathian-Pannonian Junction. Comenius University Bratislava, pp. 1-84.

Kováč, M., A. Nagymarosy, N. Oszcypko, L. Csontos, A. Slaczka, M. Marunteanu, L. Matenko, E. Márton 1998: Palinspastic reconstruction of the Carpathian-Pannonian region during the 
Miocene. - In: Rakuš, M. (Ed.) Geodynamic Development of the Western Carpathians, GUDS Bratislava, pp 198-217.

Kováč, P., M. Havrila 1997: Inner structure of Hronicum. - Slovak Geol. Mag., 4, pp. 275-280.

Kovács, I., L. Csontos, Cs. Szabó, E. Bali, Gy. Falus, K. Benedek, Z. Zajacz 2007: Paleogene-early Miocene igneous rocks and geodynamics of the Alpine-Carpathian-Pannonian-Dinaricdic region: An integrated approach. - Geol. Soc. Amer. Spec. Paper, 418, pp. 93-112.

Kovács, S. 1982: Problems of the "Pannonian Median Massif" and the distribution of Late Paleozoic-Early Mesozoic isopic zones. - Geol. Rundschau, 71, pp. 617-648.

Kovács, S. 1984: North Hungarian Triassic Facies Types: A review. - Acta Geol. Hung., 27, 3-4, pp. 251-264.

Kovács, S. 1988: Olistosromes and other deposits connected to subaqueous mass-gravity transport in the North Hungarian Paleo-Mesosoic. - Acta Geol. Hung., 31, pp. 265-287.

Kovács, S. 1992: Stratigraphy of the Szendrő-Uppony Paleozoic (Northeastern Hungary). - In: Vozár, J. (Ed.): Special Volume to the problems of the Paleozoic Geodynamic Domains, IGCP Project No. 276, pp. 93-108, GÚDS Bratislava.

Kovács, S. 1997: Middle Triassic rifting and facies differentiation in Northeast Hungary. - In: Sinha, A.K. (Ed.): Geodynamic domains in the Alpine-Himalayan Tethys, Oxford \& IBH Publishing Co. Pvt. Ltd., New Delhi, pp. 375-397.

Kovács, S. 2010: Type section of the Triassic Bódvalenke Limestone Formation (Rudabánya Hills, NE Hungary) - the north-westernmost occurrence of a Neotethyan deep water facies. - Central European Geology, (in this volume)

Kovács, S., Cs. Péró 1983: Report on stratigraphical investigation in the Bükkium, Northern Hungary. - IGCP Project 5 Newsl., 5, pp. 58-65.

Kovács, S., T. Szederkényi, J. Haas, Gy. Buda, G. Császár, A. Nagymarosy 2000: Tectonostratigraphic terranes in the pre-Neogene basement of the Hungarian part of the Pannonian area. - Acta Geol. Hung., 43, pp. 225-328.

Kovács, S., K. Brezsnyánszky, J. Haas, T. Szederkényi, F. Ebner, J. Pamić, B. Tomljenović, M. Gaetani, G.-B. Vai, H.G. Kräutner, S. Karamata, B. Krstić, J. Vozár, A. Vozárová, P. Mioč (Eds) 2004: Tectonostratigraphic terrane and paleoenvironment maps of the Circum-Pannonian region. 1: 2 500 000. - Geological Institute of Hungary, Budapest.

Kovács, S., J. Haas, G. Szebényi, Z. Gulácsi, P. Pelikán, G. Bagoly-Árgyelán, S. Józsa, Á. Görög, P. Ozsvárt, Zs. Gecse, I. Szabó 2008: Permo-Mesozoic formations of the Recsk-Darnó Hill area: stratigraphy and structure of the pre-Tertiary basement of the Paleogene Recsk Orefield. - In: Földessy, J., É. Hartai (Eds): Recsk and Lahóca geology of the Paleogene Ore Complex. Geosciences, Miskolc University Press, pp. 33-56.

Kovács, S., J. Haas, P. Ozsvárt, L. Palinkaš, G. Kiss, F. Molnár, S. Józsa, Sz. Kövér 2010: Re-evaluation of the Mesozoic complexes of Darnó Hill (NE Hungary) and comparisons with Neotethyan accretionary complexes of the Dinarides and Hellenides - preliminary data. - Central European Geology (this volume).

Kovács, S., M. Sudar, S. Karamata, J. Haas, Cs. Péró, E. Grãdinaru, H.-J. Gawlick, M. Gaetani, J. Mello, M. Polák, D. Aljinicić, B. Ogorelec, T. Kollar-Jurkovsek, B. Jurkovsek, S. Buser 2010: Triassic environments in the Circum-Pannonian region related to the initial Neotethyan rifting stage. - In: Vozár, J., F. Ebner, A. Vozárová, J. Haas, S. Kovács, M. Sudar, M. Bielik, Cs. Péró (Eds): Variscan and Alpine teranes of the Circum-Pannonian region. Slovak Academy of Sciences, Geological Institute, Bratislava, pp. 87-156.

Kövér, Sz., L. Fodor, K. Judik, T. Németh, P. Árkai, K. Balogh, S. Kovács 2008: Temperature, pressure and age constraints on the very low-grade metamorphism of the Jurassic Telekesoldal nappe (Inner Western Carpathians) in NE Hungary - a summary. - International Meeting of Young Researchers in Structural Geology and Tectonics, Oviedo (Spain) Abstract, pp. 391-395.

Kövér, Sz., J. Haas, Á. Görög, P. Ozsvárt, A. Götz, S. Józsa 2009: Lithofacies and age data of Jurassic foreslope and basin sediments of Rudabánya Hills (NE Hungary) and their tectonic interpretation. - Geologica Carpathica, 60/5, pp. 351-379. 
Kozur, H. 1991: The evolution of Meliata-hallstatt ocean and its significance for the evolution of te Eastern Alps and Western Carpathians. - Palaeo. Palaeo. Palaeo., 86, pp. 108-135.

Kozur, H., R. Mock 1973: Zum Alter und tektonischen Stellung der Meliata-Serie des Slowakischen Kartes. - Geol. Zbor. - Geol. Carp., 24, pp. 365-374.

Kozur, H., R. Mock 1985: Erster Nachweis von Jura in der Meliata-Einheit der südlichen Westkarpaten. - Geol. Paläont. Mitt., 13, pp. 223-238.

Kozur, H., R. Mock, L. Ozvoldová 1996: New biostratigraphic results in the Meliaticum in its type area around Meliata village (Slovakia) and their tectonic and paleogeographic significance. Geol. Paläont. Mitt., 21, pp. 89-121.

Kozur, H., H. Mostler 1992: Erster paläontologischer Nachweis von Meliaticum und Südrudabanyaicum in den Nördlichen Kalkalpen (Österreich) und ihre Beziehungen zu den Abfolgen in den Westkarpaten. - Geol. Paläont. Mitt. Innbruck, 18, pp. 87-129.

Kozur, H., Zs. Réti 1986: The foirstpaleontological evidence of Triassic ophiolites in Hungary. Neues Jahrb. Geol. Paleont. Mh., 5, pp. 284-292.

Less, Gy. 2000: Polyphase evolution of the structure of the Aggtelek-Rudabánya Mountains (NE Hungary), the southernmost element of the Inner Western Carpathians - a review. - Slovak Geological Magazine, 6, pp. 260-268.

Less, Gy., J. Mello (Eds) 2004: Geological map of the Gemer-Bükk area 1: 100.000. - Geological Institute of Hungary, Budapest.

Less, Gy., M. Báldi-Beke, S. Pálfalvi, J. Földessy, B. Kertész 2008: New data on the age of the Recsk volcanics and the adjacent sedimentary rocks. - In: Földessy, J., É. Hartai (Eds): Recsk and Lahóca geology of the Paleogene Ore Complex.- Geosciences, Miskolc University Press, pp $57-84$.

Machel, M. 1986: Geological structure of Czechoslovak Carpathians. - Vol. 1, Paleoalpine unit Bratislava, 503 p. (In Slovak.)

Majoros, Gy. 1980: Problems of Permian sedimentation in the Transdanubian Central Range. A paleogeographic model and some consequences. - Földt. Közl., 110, pp. 323-341. (In Hungarian.)

Majzon, L. 1956: New stratigraphic results of Hungarian oil-prospecting borings. - Földt. Közl., 86, pp. 44-58. (In Hungarian.)

Mandl, G.W., A. Ondrejickova 1991: Über eine triadische Tiefwasserfazies (Radiolarite, Tonschiefer) in den Nördlichen Kalkalpen - ein Vorbericht. - Jb. Geol. B-A, 143, pp. 309-318.

Mandl, G.W., A. Ondrejickova 1993: Radiolarien und Conodonten aus dem Meliatikum im Ostabschnitt der Nördlichen Kalkalpen Österreich. - Jb. Geol. B-A, 136, pp. 841-871.

Márton, E. 1987: Paleomagnetism and tectonics in the Mediterranean region. - J. Geodyn., 7, pp. $33-57$.

Márton, E., P. Márton 1978: On the difference between the paleomagnetic poles from the Transdanubian Central mountains and the Villány Mountains respectively. - Magyar Geofizika, 19, pp. 129-136.

Márton, E., L. Fodor 1995: Combination of paleomagnetic and stress data-case study from North Hungary. - Tectonophysics, 242, pp. 99-114.

Márton, E., L. Fodor 2003: Tertiary paleomagnetic results and structural analysis from the Transdanubian Range (Hungary); sign for rotational disintegration of the Alcapa unit. Tectonophysics, 363, pp. 201-224.

Mello, J., M. Polák, A. Ondrejicková 1995: Mesozoic radiolarites of central and inner part of the West Carpathians. - 15th Congr. Carp. Balk. Geol. Ass., Reports, Geol. Soc. Greece, Athens, 4, pp. 232-236.

Mello, J., M. Elecko, J. Pristaš, P. Reichwalder, L. Snopko, D. Vass, A. Vozárová, L. Gaál, V. Hanzel, J. Kók, P. Kovác, M. Slavkay, A. Steiner 1997: Explanatory text to the Geological map of Slovak Karst. - D. Štúr Publ., pp. 1-255.

Mello, J. (Ed.), I. Filo, M. Havrila, J. Ivanicka, J. Madarás, Z. Németh, M. Polák, J. Pristaš, J. Vozár, E. Koša, S. Jr. Jacko 2000: Geological map of the Slovenský Raj-Galmus Mts. and Hornád 
Deppression 1 : 50 000. Reg. geol. maps of Slovakia 1 : 50 000. Vydali Min. Zivot. Prostr. SR Štátny geologický ústav D. Štúra, Bratislava.

Mock, R., M. Sýkora, R. Aubrecht, L. Ozvaldová, B. Kronome, R.P. Reichwalder, J. Jablonský 1998: Petrology and stratigraphy of the Meliaticum near the Meliata and Jaklovce villages, Slovakia. Slovak Geol. Mag., 4, pp. 223-260.

Palinkaš, L.A., V. Bermanec, S. Borojevic Šoštarić, T. Kolar-Jurkovšek, Strimic Palinkaš, F. Molnár, G. Kniewald 2008: Volcanic facies analysis of a subaqueous basalt lava-flow complex at Hruškovec, NWCroatia - Evidence of advanced rifting in the Tethyan domain. - J. Volcanol. Geotherm. Res. doi. 10.1016.

Pamić, J. 1997: The northwesternmost outcrops of the Dinaridic ophiolites: A case study of Mt. Kalnik (North Croatia). - Acta Geol. Hung., 40, pp. 37-56.

Pamić, J., V. Jelaska, I. Gusić, K. Sikic, M. Belak, V. Tomić 1997: Tectonostratigraphic and terranes between the Adriatic Sea and the southern Pannonian Basin. - Ann. Géol. Pays Helléniques, 37, pp. 401-407.

Pamić, J. 2000: The Sava-Vardar Zone (SVZ). - Vijesti, 37, pp. 19-22.

Pamić, J. 2002: The Sava-Vardar Zone of the Dinarides and Hellenides versus the Vardar Ocean. Eclogae Geol. Helv. 95, pp. 99-113.

Pamić, J. 2003: The allochthonous fragments of the Internal Dinaridic units in the western part of the South Pannonian Basin. - Acta Geol. Hung., 46, pp. 41-62.

Pamić, J., B. Tomljenović 1998: Basic geological data on the Croatian part of the Mid-Transdanubian Zone, as exemplified by Mt. Medvednica located along the Zagreb-Zemplin Fault Zone. - Acta Geol. Hung., 41, pp. 389-400.

Pamić, J., B. Tomljenović, D. Balen 2002: Geodynamic and petrogenetic evolution of Alpine ophiolites from the Central and NW Dinarides: An overview. - Lithos, 65, pp. 113-142.

Papanikolau, D., G. Migiros, S. Kovács, Z. Gulácsi 2006: Re-interpretation of the Bükk tectonostratigraphy: from the Bükk platform to the Bükk basin and the Szarvaskő Ocean. - XVIIIth Congress Carpathian-Balkan Geol. Assoc. Proc., pp. 432-434.

Pelikán, P. (Ed.) 2005: Geology of the Bükk mountains. - MÁFI, Budapest, 284 p.

Pelikán, P., L. Dosztály 2000: Jurassic formations of the Bükkzsérc boreholes (SW Bükk Mts., NE Hungary) and their structural setting. - Földt. Közl., 130, pp. 25-46. (In Hungarian.)

Péró, Cs., S. Kovács, Gy. Less, L. Fodor 2002: Tectonic setting of the Triassic Hallstatt (s.1.) facies in NE Hungary. - Geol. Carpath. Spec. Issue. Proc. XVIIth Carp.-Balk. Geol. Congr. Bratislava, pp. $24-25$.

Péró, Cs., S. Kovács, Gy. Less, L. Fodor 2003: Geological setting of Triassic "Hallstatt" (s.1.) facies in NE Hungary. - Ann. Univ. Sci. Budapest. Sect. Geol. 35, pp. 58-60.

Pešić, L., A. Ramovš, J. Stremac, S. Pantić-Prodanović, I. Filipović, S. Kovács, P. Pelikán 1986: Upper Permian deposits of the Jadar region and their position within the Western Paleotethys. - Mem. Soc. Geol. It., 34, pp. 211-219.

Plašienka, D., P. Grecula, M. Putiš, D. Hovorka, M. Kováč 1997: Evolution and structure of the Western Carpathians: an overview. - In: Grecula, P., D. Hovorka, M. Putiš (Eds): Geological evolution of the Western Carpathians. Bratislava, pp. 1-24.

Protić, L., I. Filipović, P. Pelikán, D. Jovanović, S. Kovács, M. Sudar, K. Hips, Gy. Less, R. Cvijić 2000: Correlation of the Carboniferous, Permian and Triassic sequences of the Jadar Block, Sana-Una and "Bükkium" Terranes. - In: Karamata, S., S. Janković (Eds): Proceedings of the International Symposium Geology and Metallogeny of the Dinarides and Vardar Zone. Banja Luka, pp. 61-69.

Rálish-Felgenhauer, E. 1998: Stratigraphy of the Paleozoic and Mesozoic formations of the MidTransdanubian area. - In: Bérczi, I., Á. Jámbor (Eds): Stratigraphy of geological formations of Hungary, MÁFI - MOL Rt. Budapest, pp. 155-172. (In Hungarian.)

Ramovš, A. 1989: Permian in Slovenia in: Permian and Permian-Triassic boundary in the SouthAlpine segment of the Western Tethys. - Field guide book, IGCP Project, 203, Brescia, pp. 11-13. 
Ratschbacher, L., W. Frisch, H-G. Linzer, O. Merle 1991: Lateral extrusion in the Eastern Alps. Part 2, Structural analysis. - Tectonics, 10, pp. 257-271.

Réti, Zs. 1985: Triassic ophiolite fragments in an evaporitic melange, Northern Hungary. - Ofioliti, 10, pp. 411-422.

Robertson, A.H.F. 2004: Development of concepts concerning the genesis and emplacement of Tethyan ophiolites in the Eastern Mediterranean and Oman regions. - Earth-Sci. Rev., 66, pp. 331-387.

Robertson, A.H.F. 2007: Overview of tectonic settings related to the rifting and opening of Mesozoic ocean basins in the Eastern Tethys: Oman, Himalayas and Eastern Mediterranean regions. - In: Karner, G.D., G. Manatschal, L.M. Pinhiero (Eds): Imaging and Modelling Continental Lithosphere Extension and Breakup. Geol. Soc., London, Spec. Publ., 282, pp. 325-388.

Robertson, A.H.F., S. Karamata 1994: The role od subduction-accretion processes in the tectonic evolution of the Mesosoic Tethys in Serbia. - Tectonophysics, 234, pp. 73-94.

Robertson, A., S. Karamata, K. Šarić 2009: Overview of ophiolites and related units in the Late Paleozoic-Early Cenozoic magmatic and tectonic development of Tethys in the northern part of the Balkan region. - Lithos, 108, pp. 1-36.

Royden, L.H. 1988: Late Cenozoic tectonics of the Pannonian Basin system. - In: Royden, L.H., F. Horváth (Eds): The Pannonian Basin. A study in basin evolution. AAPG Memoir, 45, pp. 27-48.

Rožič, B., T. Popit 2006: Redeposited limestones in the Middle and Upper Jurassic successions of Slovenian basin. - Geologija, 49, pp. 219-234.

Schmid, S.M., D. Bernoulli, B. Fügenschuh, L. Matenco, R. Schuster, S. Schefer, M. Tischler, K. Ustaszewski 2008: The Alpine-Carpathian-Dinaridic orogenic system: correlation and evolution of tectonic units. - Swiss J. Geosci, 101, pp. 139-183.

Schréter, Z. 1936: Lyttonia aus dem Bükk-Gebirge. - Földt. Közl., 66, pp. 113-121.

Schréter, Z. 1943: A Bükk-hegység geológiája (Geology of the Bükk Mts.). - Besz. Kir. Földt. Int., 5, 7, pp. 378-411.

Schréter, Z. 1959: A Bükk hegység tengeri eredetû́ permi képződményei (Formations of marine origin of the Bükk Mountains). - Földt. Közl., 89, pp. 364-373. (In Hungarian.)

Šmuc, A., J. Car 2002: Upper Ladinian to Lower Carnian sedimentary evolution in the Idrija Cerkno region, Western Slovenia. - Facies, 46, pp. 205-216.

Szalai, T. 1961: A Tisia és a Pannonikum belsőhegysége (Internal mountain of the Tisia and Pannonicum). - Földr. Ért., 10, pp. 439-461. (In Hungarian.)

Szepesházy, K. 1975: Geological setting of the NE Carpathians and their position in the Carpathian system. - Ált. Földt. Szemle, 8, 25-60. (In Hungarian.)

Szoldán, Zs. 1990: Middle Triassic magmatic sequences from different tectonic settings in the Bükk Mountains (NE Hungary). - Acta Miner. Petr. Szeged., 31, pp. 25-42.

Sztanó, O. 1990: Submarine fan-channel conglomerate of Lower Cretaceous, Gerecse Mts., Hungary. - Neues Jahrbuch für Geologie und Paläonttologie Monatshefte, 7, pp. 431-446.

Schweigl, J., F. Neubauer 1997: Structural evolution of Northern Caslcareous Alps: Significance forthe Jurassic to Tertiary geodinamics in the alps. - Ecl. GEol. Helv., 90, pp. 303-323.

Tilšjar, J., I. Vlahović, I. Velić, B. Sokac 2002: Carbonate platform megafacies of the Jurassic and Cretaceous deposits of the Karst Dinarides. - Geol. Croatica, 55, 139-170.

Tomljenović, B. 2002: Structural characteristics of the Mts. Medvednica and Samobor. - Unpubl. Ph.D. Thesis, Univ. of Zagreb, 207 p. (In Croatian.)

Tomljenović, B., L. Csontos, E. Márton, P. Márton 2008: Tectonic evolution of the northwestern Internal Dinarides as constrained by structures and rotation of Medvednica Mts., North Croatia. - In: Siegesmund, S., B. Fügenschuh, N. Frotzheim (Eds): Tectonic aspects of the Alpine-Dinaride-Carpathian System. - Geol. Soc. Spec. Publ., 298, pp. 145-168.

Ustaszewski, K., S.M. Schmid, B. Fügenschuh, M. Tischler, E. Kissling, W. Spakman 2008: A mapview restoration of the Alpine-Carpathian-Dinaridic system for the Early Miocene. - In: Froitzheim, N., S.M. Schmid (Eds): Orogenic processes in the Alpine collision zone, Swiss Journal of Geosciences 101/Supplement 1, S273-S294. 
Vai, G.B. 1994: Crustal evolution and basement elements in the Italian area: paleogeography and characterization. - Boll. Geof. Teor. Appl., 36, pp. 411-434.

Vai, G.B. 1998: Field trip trough the Southern Alps: an introduction with geologic settings, palaeogeography and Palaeozoic stratigraphy. - In: Perri, M.C., C. Spalletta (Eds): Southern Alps Field Trip Guidebook. - ECOS 7. Giorn Geol. ser. 3a, Bologna 60 Spec. Issue, pp. 1-38.

Vai, G.B. 2003: Development of the palaeogeography of Pangaea from Late Carboniferous to Early Permian. - Palaeo. Plalaeo. Palaeo., 196, pp. 125-155.

Velledits, F. 2000: A Berva-völgytől a Hór-völgyig terjedő terület fejlődéstörténete a középső-felső triászban (Evolution of the area from the berva Valley to the Hór Valley in the Middle - Upper Triassic). - Földt. Közl., 130, pp. 47-93.

Velledits, F, Cs. Péró, J. Blau, B. Senowbari-Daryan, S. Kovács, O. Piros, T. Pocsi, H. Szügyi-Simon, P. Dumitricã, J. Pálfy 2008: The oldest Triassic barriere reef from the western Tethys (NE Hungary). - Erlanger Geologische Abhandlungen, Sonderband, 6 (78. Jahrestagung der Paläontologischen Gesellschaft), Erlangen, pp. 69-70.

Vojtko, R. 2000: Are there tectonic units derived from the Meliata-Hallstatt trough incorporated into the tectonic structure of the Tisovec Karst? (Murán karstic plateau, Slovakia). - Slov. Geol Mag., 6, 4, pp. 335-346.

Vozárová, A., J. Vozár 1992: Tornaicum and Meliaticum in borehole Brusník BRU-1, Southern Slovakia. - Acta Geol. Hung., 35, pp. 97-116.

Vozárová, A., F. Ebner, S. Kovács, H-G. Krautner, T. Szederkényi, B. Krstić, J. Sremac, D. Aljinović, M. Novak, D. Skaberne 2009: Late Variscan Carboniferous to Permian environments in the Circum Pannonian Region. - Geol. Carp. 60, pp. 71-104.

Wein, Gy. 1969: Tectonic review of the Neogene-covered areas of Hungary. - Acta Geol. Hung., 13, pp. 399-436.

Wein, Gy. 1972: Magyarország neogén előtti szerkezetföldtani fejlődésének összefoglalása (Sumary of pre-Neogene stucture evolution of Hungary). - Földr. Közl., 96, pp. 302-328.

Wein, Gy. 1978: Alpine-type tectogenesis of the Carpathian Basin. - Ann. Rep. Hung. Geol. Inst., on 1976, pp. 245-256. 